\author{
UNIVERSIDADE DE SÃO PAULO \\ FACULDADE DE CIENCIAS FARMACRUTICAS \\ Curso de Pós.graduação em \\ Ciência dos Alimentos
}

\title{
AÇÃO DA SOJA SOBRE A TIREÓIDE DE RATOS INFLUÉNCIA DO IODO DA RAÇÃO
}

TULLIA M. C. C. FILISETTI-COZZI
Tese para obtenção do título de DOUTOR

Orientador:

Prof. DI. FRANCO M. LAJOLO 
A você, Carlos

pelo estímulo, pela compreensão, pela paciência, etc, .......... 
SUMĀRIO

pàg.

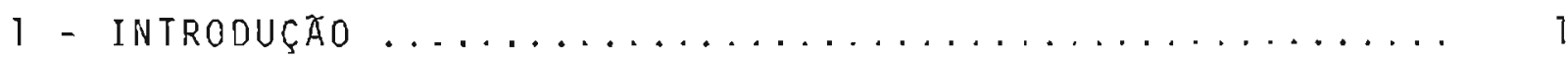

$2-$ METODOS ............................ 6

2.1 - Fracionamento da Soja ................... 6

2.1.1 - Obtenção da Farinha Desengordurada e Auto clavada (FDA) .................. 6

2.1.2 - Obtenção do Resíduo Extração com Ägua, Extra to Aquoso e Fração Acetônica........... 7

2.1 .3 - Obtenção do Resîduo Metanol-Acetona..... 9

2.1 .4 - Obtenção do hidrolisado e Resĩduo da Hidrōise ...................... 9

2.2 - Ensaios com Animais ................... 10

2.2.1 - Ensaios agudos (Frações de baixo peso molecular) ..................... 10

2.2 .2 - Ensaios com rações contendo iodo ........ 13

2.2 .3 - Ensaios usando rações com restrição de iodo ...................... 14

2.2 .4 - Ensaios com produtos resultantes da hidrö 1 ise enzimätica .................. 15

2.3 - Determinação da Porcentagem de Captáção Relativa. 15

2.4 - Dosagem dos Hormónios da Tireóide ............ 15

2.4 .1 - Preparo do hidrotisado ............ 15

2.4 .2 - Cromatografia dos hormōnios marcados .... 16

2.4.3 - Medida da radioatividade dos hormónios ti reoidianos ..................... 17

2.5 - Dosagem dos Hormônios sëricos .............. 17

2.6 - Métodos Histológicos e Histoquĩmicos ............ 18

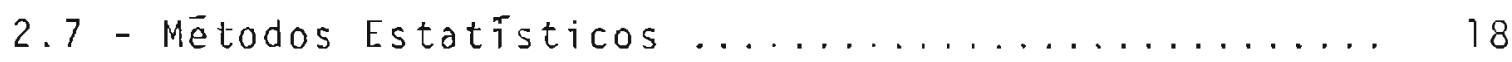

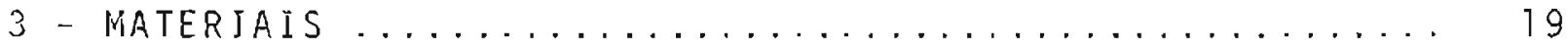

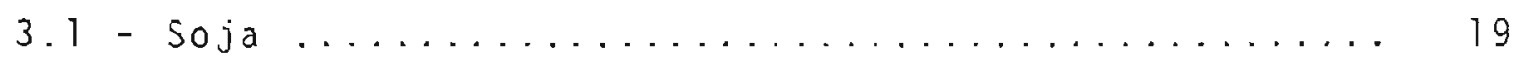


pāg.

3.2 - Animais ......................... 19

3.3 - Raçöes Experimentais .................. 20

3.3.1 - Rações contendo iodo (Ensaios com a fração de baixo peso molecular) ............ 20

3.3 .2 - Rações com restrição de iodo (Ensaios com frações de baixo ou alto peso molecular.. 20

3.4 - Iodo Radioativo ................... 24

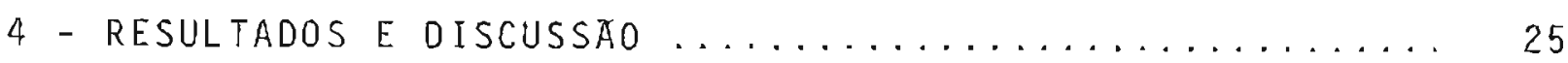

4.1 - Ensaios com Raçōes Contendo Iodo. Efeito da Fração Acetōnica ......................... 26

4.2 - Ensaios com Rações com Restrição dẹ lodo ....... 30

4.2.1 - Efeito das frações de baixo peso molecu lar ............................. 31

4.2.2 - Efeito das frações de alto peso molecular 34

4.3 - Exame Anatomopatológico da Tireóide ........... 40

4.3 .1 - Exame Macroscōpico ............... 41

4.3 .2 - Exame Microscōpico ................4 41

4.4 - Efeito dos Produtos da Hidrōlise Enzimätica.... 45

5 - Referencias Bibliograficas .................. 50

RESUMO $\ldots \ldots \ldots \ldots \ldots \ldots \ldots \ldots \ldots \ldots \ldots \ldots$

SUMMARY ......................... 59 
1 - INTRODUÇAO

Substâncias que agem direta ou indiretamente na tireöide podem ser encontradas em inümeros vegetais consumidos pelo ho mem $(5)(6)(16)(17)(60)(65)(69)$. A maioria delas é bem conhecida, tem estrutura química já definida e pertence ao grupo dos cianatos (22), tiocianatos, isotiocianatos, nitrilas, tiooxazolidonas (11), nitratos e nitritos $(65)(68)$, dissulfetos ${ }^{(49)}$ ou dos flavonóides (23) $(36)(46)(47)(48)(52)$.

Ao 1 ado dessas substancias bociogēnicas conhecidas, exis tem outras, cuja natureza e açăo não foram ainda bem caracteriza das, comoè o caso do fator existente na soja(32).

A revisão da literatura mostra que os värios pesquisado res atribuem a causas diversas, os diferentes efeitos causados pela soja sobre a tireóide, sendo que alguns riegam mesmo a existência de qualquer ação direta.

MCCARRISON (35) foi o primeiro a descrever a ocorréncia de um aumento no peso da tireóide em ratos alimentados com soja.

Estudos posteriores de outros autores demonstraram que esse efeito poderia ser revertido, parcialmente, por aquecimento da soja e, totalmente, pela ingestão de iodo em quantidades um pouco acinic das necessärias $(18)(54)(64)$. Efeitos semelhantes, medidos porém pela redução na captação de iodo radioativo, foram observados tanto em ratos ${ }^{(28)}$ como em crianças alérgicas $(63)$ ali- 
Ao Prof. Franco M. Lajolo, pela orientaçāo e interesse com que acompanhou nossos trabalhos; à Coordenadoria de Aperfeiçoamento do Pes soal de Nivel Superior (CAPES) e Conselho Nacional de Desenvolvimento Cientifico e Tecnológico (CNPq), pela concessão de bolsas de estudos durante os anos de 1978 e 1979; à Financiadora de Estudos e Projetos (FINEP) pelo financiamento da pesquisa; à Comissão Nacional de Energia Nuclear - CENEN São Paulo pelo fornecimento do material radioativo; à Escola Superior de Agronomia de Lavras, Instituto Agronōmico de Campinas - Seção Leguminosas, Cooperativa Mogiana de Oleos Vegetais COMOV pelo fornecimento das amostras de soja; à Central de Radioimunoensaio de São Paulo, à colega Célia Colli e ao Prof. José Carlos Barbé rio, pelo auxilio técnico nos testes de radioimunoensaio; à Profa. Silvia Berlanga de Moraes Barros e ar Prof. Helio Bisi pelo auxílio técnico e na interpretação dos resultados nos ensaios anatomopatológi cos; aos colegas Ursula M. Lanfer Marquez, Maria Oriana Reyes Figueroa, Alfredo Tenuta Filho, Elisabeth Garcia, Flävio Finardi Filho, Elizabe te Wenzel de Menezes e Celly Akemi Donomai pelos auxílios técnicos pres tados nos momentos mais críticos, à Loanda d'Eurydice pela compreensão e eficiente execução da datilografia; à bibliotecária Maria Amélia Rocha Costa do Conjunto das Químicas da USP, pela revisão e normalização das referencias bibliogräficas; aos demais colegas e funcionários dó Departamento de Alimentos e Nutrição Experimental da Faculdade de Cién cias Farmacéuticas da USP que sempre, de alguma forma, colaboraran co nosco.

E aos nossos pais e amigos pelo apoio, coragem e confiançe que sempre nos transmitiram

nossos agradecimentos 
mentadas com leite de soja.

Por outro lado, opostamente, outros autores observaram um aumento na captação de iodo marcado, tanto em ratos (3)(61) como em crianças alimentadas com producos derivados de soja $(19)(45)(55)$. Esses efeitos foram atribuĩdos a uma ação indireta: haveria um au mento na excreção fecal de tiroxina endógena reduzindo consequen temente a sua possibilidade de recuperação pela circulação entero-hepätica.

Outra linha de observações é trazida pelas pesquisas de NORDSIEK ${ }^{(42)}$ que verificou haver um aumento do peso da tireóide, em ratos alimentados com raçōes contendo de 35 a $60 \%$ de soja crua ob servando, porēm, que a adição de caseīna, uma proteĩna nutricio nalmente melhor, à ração, eliminava aquele efeito.

Nesse caso o efeito bociogênico poderia estar relacionado, pelo menos em parte, com a baixa digestibilidade da proteina de soja crua.

os resultados apresentados por värios autores, em muitos casos, são difíceis de serem comparados, pelo fato de que a soja não processada termicamente, tem fatores anti-nutricionais que podem interferir com o crescimento normal e, portanto.com a fisiologia da tireóide $(31)(32)(33)(50)(51)(66)$.

Igualmente ao que se observa para o efeito biolōgico, muito pouco tem sido estabelecido sobre as propriedades químicas do possivel fator. Alguns autores conciuíram que ele pode ser precipitado com éter, clorofórmio, acetona e etanol $(18)(64)$, ao passo que outros observaram uma solubilidade parcial em éter e acetona $(54)$.

Trabalhos mais recentes constataran a presenca de um 
agente tireoidiano na farinha de soja desengordurada não aquecida $(28)$, que resiste à digestão pancreātica e ao aquecimento em ba nho-maria fervente, mas $\bar{e}$, aparentemente, destruĩdo pelo tostamen to da farinha e, quando incorporado a dieta, aumenta a capacidade de ligação daß-prote ênas, séricas ä̃ trijodotironina $\left(T_{3}\right)$ exōgena radioativar A glàndula quando exposta "in vitro"(29) a esse agente depressor da captação de $I^{131}$, apresenta uma incorporação menor de radioiodo na forma de dijodotirosina (DIT) e um aumento da relação triodotironina/tiroxina $\left(T_{3} / T_{4}\right)$ radioativos.

Trabaihos realizados em nosso laboratōrio demonstraram que extratos obtidos de produtos comerciais processados de soja(14), foram capazes de diminuir a captação de Il31 pela tireoide, em ensaios de $24 \mathrm{~h}$ de duração.

Em estudos posteriores (12) confirmamos que, de fato, havia na soja um fator resistente à autociavagem por $1 \mathrm{~h}$ a $121^{\circ} \mathrm{C}$, c $\underline{a}$ paz de reduzir a captação de iodo desde 6 h até $24 h$ apös a sua ingestão.

Ainda, em outro trabalho subsequente(13), conduzimos estudos por tempos mais longos (16 e 29 dias) com frações de soja crua ou autoclavada; e verificamos que a ingestão por 16 dias de farinha crua causou aumento de $40 \%$ no peso da tireóide, redução semelhante na porcentagem de captação de $I^{131}$ e um aumento na capacidade sérica de ligação da trijodotironina radioativa exō gena. Porēm, a fração apōs a autoclavagem, provocou uma redução na capacidade sérica do $T_{3}$ nos ensaios de 16 dias e nos de 29 dias, observamos uma diminuição no peso da tireóide e um aumento na\% de captação.

Nos ensaios de 29 dias essa mesma fração provocou tambēm uma alteração dos hormōnios tireoidianos 
representada por um aumento da velocidade de sintese de $T_{3}$ e $T_{4}$ respectivamente redução da relação $T_{3} / T_{4}$ e um aumento da relä çāo MIT/DIT.

Porēm, problemas de crescimento devidesà presença de fä tores anti-nutricionais na soja crua e a existéncia de iodo em excesso nas rações utilizadas dificultaram uma interpretação ace 1 tável do mecanismo de ação.

Nessa mesma linha de trabalho, que estamos desenvolvendo, conseguimos compilar da literatura os estudos de SUWA e KIMU$R A(57)$. Esses autores detectaram ação bociogēnica em produtos de soja em condições de baixa ingestão de iodo, que foi atribuida a uma fração extraĩda com metanol a $90 \%$, solūvel em acetona e butanol e insolüvel em ēter etîlico. Pelo menos um dos compostos ativos foi identificado como sendo uma saponina.

Pouco se sabe ainda sobre o significado biológico a Ion go prazo dessa ação da soja. KIMURA e cols. (26) porém, alertaram para observaçōes que fizeram, de que ratas submetidas a raçóes de soja e, em condições de deficiência em iodo, apresentavam sinais de tumores malignos na tireóide.

Recentemente somam-se ainda as observações de KIMURA ${ }^{(24)}$ e KIMURA e cols. (25) que tambēm detectaram ação bociogēnica em produtos de soja produzidos no japão.

Pelo descrito acima verificamos a importāncia do estudo desse "fator" presente na soja, uma vez que ela vem sendo introduzida cada vez mais na formulação de alimentos destinados a programas oficiais de alimentação de grupos vulnerāveis forneci dos, inclusive, a crianças desnutridas. Alëm disso, ela vem sendo utilizada pela indústria alimenticia na produção de diversos 
alimentos, com finalidade variada: dietéticas ou tecnológicas. As sim sendo esse "fator" poderá atuar em indivíduos em estados nutricionais ou de saúde os mais variados possiveis e, como consequēncia poderá induzir alteraçōes na tireóide de significados dis tintos, conforme o caso.

o presente trabalho tem por objetivo, estudar a ação na tireóide de ratos, de algumas fraçōes de baixo e alto peso molecu lar, obtidas da farinha de soja desengordurada e autoclavada, quan do fornecidos em rações com e sem iodo, na tentativa de obter informações sobre sua natureza, mecanismo de ação e, consequentemen te, inferir sobre o seu significado biolögico. 


\section{1 - Fracionamento da Soja}

Da soja integral obteve-se, inicialmente, a Farinha Desen gordurada e Autoclavada (FDA); esta foi, a seguir, tratada de diver sas formas para a preparaçāo de duas grandes frações que foram de nominadas de "fração de baixo peso molecular"e "fração de alto peso molecular". A fração de baixo peso molecular compreende duas sub-frações: Extrato Aquoso e Fração Acetōnica. A de alto peso molecular compreendeu: a FDA, Resĩduo de Extração com Agua e Resíduo da Extração com Metanol e Acetona.

2.1.1 - Obtenção da Farinha Desengordurada e Autoclavada (FDA)

A soja foi moida em moinho de facas com peneira de diâmetro $0,127 \mathrm{~cm}$ e, em seguida, desengordurada com éter etî́ico durante 20 horas, em aparelho de soxhlet. 0 solvente residual da farinha foi removido em capela, sob ventilação, e o material mo ido novamente, nas mesmas condições.

A farinha desengordurada obtida foi misturada con àgua destilada na proporção de 10:75 (soja:āgua) e autoclavada durante 30 minutos a $121^{\circ} \mathrm{C}$. Porções de 100 gramas de farinha foram adicionadas a $750 \mathrm{~m} 7$ de àgua destilada e autoclavadas em recipientes 
de aço inoxidāvel de dois litros e meio. Após secagem em estufa a $55^{\circ} \mathrm{C}$ com circulação de ar, por 8 horas, o material foi novamente moido. Na farinha resultante (FDA) avaliou-se o teor de umida de (43) proteinas $(2)$ e fibre $(62)$ obtendo-se, respectivamente, os seguintes valores: $5,3 \%, 49,8 \%(N \times 5,71)$ e $9,2 \%$.

\subsection{2 - Obtenção do Resïduo da Extração com Agua, Extrạ to Aquoso e Fração Acetōnica (Figura 1)}

Apōs tratamento tērmico em autoclave à suspensão em àgua da FDA foi acidificada com HCl in atē pH 4,2 (ponto isoelē trico da proteina de soja), submetida a agitação por uma hora a temperatura ambiente e a seguir centrifugada a 7000 r.p.m. duran te 20 minutos. 0 resíduo foi reextraído com $250 \mathrm{ml}$ de àgua desti lada nas mesmas condições.

o resíduo final resultante deu origem ao Residuo de Extração com Äguá, apōs secagem em estufa com circulação de ar a $55^{\circ} \mathrm{C}$ por 10 horas e posterior moagem. A determinação do teor de umidade(43), proteina $(2)$ e fibra (62) foi respectivamente de: $7,7 \%, 57,7 \%(N \times 5,71)$ e $73,4 \%$.

os sobrenadantes resultantes desse tratamento foram: a) concentrados em evaporador rotatōrio à väcuo em b.m. a $50^{\circ} \mathrm{C}$ até volume de $50 \mathrm{ml}$ (para $100 \mathrm{~g}$ de FDA), resultando o Extrato Aquo so, ou b) foram submetidos a tratamento com acetona na proporção de 2:1 (acetona:sobrenadante) e deixadas em repouso por 10 ho ras a $4^{\circ} \mathrm{C}$. Apōs fijtração o filtrado foi concentrado a vácuo em b.m. a $50^{\circ} \mathrm{C}$ até volume de $50 \mathrm{ml}$ (para $100 \mathrm{~g}$ de FDA) originando a Fração Acetônica(28). 


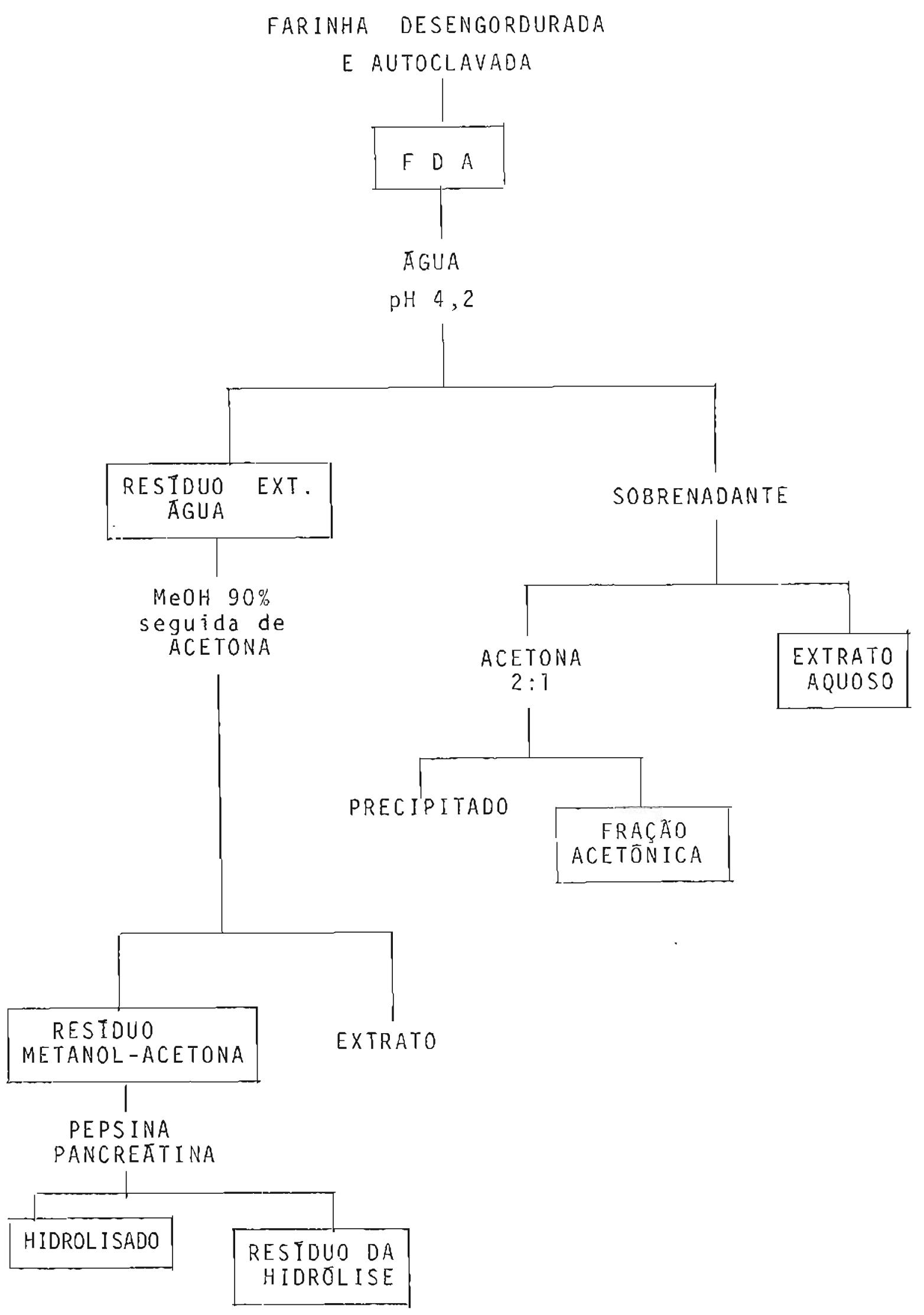

FIGURA 1 - Esquema Geral de fracionamento da farinha desengordura da e autoclavada. As fraçöes enquadradas foram aquelas ensaiadas experimentalmente. 


\subsection{3 - Obtenção do Resĩduo Metanol-Acetona}

O resĩduo da Extração com Agua foi tratado com metanol a $90 \%$ em extrator de Soxhlet durante 24 hs e apös secagem em cape la com ventilação, foi submetido a uma segunda extração, agora com acetona durante mais 24 hs. 0 material final, após seco por ventilação apresentava ainda traços de solventes, sendo neces särio hidratā-io para posterior secagem; esta coi conduzida em es tufa a $55^{\circ} \mathrm{C}$ por mais 8 horas. 0 produto assim obtido foi chamado de Resíduo Metanol-Acetona (Figura 1 ).

$$
\text { Os teores de Umidade(43), proteina }(2) \text {, cinza }{ }^{(43)} \text { e fibra }
$$
total e solūvel pelo método enzimätico(l) (descontando-se a proteîna e cinza) foram respectivamente de: $7,9 \%, 60,2 \%, 1,9 \%, 30,3 \%$ e $6,12 \%$.

2.1.4 - obtenção do Hidrolisado e Resíduo da Hidrólise

o Residuo Metanol-Acetona $(1177 \mathrm{~g})$ foi misturado com āgua destilada a $50^{\circ} \mathrm{C}$ na proporção de $1: 30$ (Resĩduo Metanol-Aceto na:Agua) resultando uma concentração fina? de substrato (proteina) de $5,6 \%$. A mistura resultante foi acidificada com HCl $4 M$ atē atingir o pH de 1,7 e submetida à hidröise enzimätica com pepsina (Biobras-300oNF) na proporção de 2:100 (enzina:proteĩna) a $50^{\circ} \mathrm{C}$ em càmara quente durante duas horas, con agitação.

Terminada a primeira hidrōlise o pH foi elevado para 8,0 com auxilio de $\mathrm{NaOH}$ 4M submetendo-se a mistura a uma segun da hidrölise com pancreatina (Sigma P-1750) na proporção de 2:100 
(enzima:proteina) por 18 horas a $45^{\circ} \mathrm{C}$. Durante as duas primeiras horas o pH da mistura foi mantido constante em torno de 8,0 com a uxîlio de um pipetador automático acoplado a um potenciometro, para evitar a acidificação brusca nas primeiras horas. Finda a hidrölise as enzimas foram inativadas em b.m. fervente por $10 \mathrm{mi-}$ nutos. Após esfriamento em banho de gelo o pH foi corrigido para 7,0 com HCl 4M, a suspensão centrifugada a 8.000 r.p.m. durante uma hora e o centrifugado foi filtrado em funil de Büchner à vácuo. 0 residuo resultante foi reextra ido, com três 1 itros de āgua desti lada, durante uma hora, com agitação, e submetido ao mesmo tratamento citado acima, sendo finalmente secado em estufa com circulação de ar a $55^{\circ} \mathrm{C}$ durante 10 horas e moido, constituindo-se no Res îduo da Hidrölise (Figura l). Os sobrenadantes foram concentrados à vācuo em b.m. a $50^{\circ} \mathrm{C}$ obtendo-se assim o Hidrolisado (Figura 1).

os teores de umidade(43), proteina(2), cinza(4.3) e extrato etéreo ${ }^{(43)}$ do Hiarolisado foram respectivamente: $70,9 \% ; 19,9 \%$ $(\mathrm{N} \times 5,71) ; 4,08 \%$ e $0,41 \%$ e os do Residuo da Hidrōlise foram: 9,0\%; $35,7 \%$ (sendo $12,5 \%$ não biodisponível); $5,4 \%$ e $0,84 \%$. 0 teor de fí bra total (mētodo enzimätico) (1) do Resíduo da Hidrōlise foi equi valente a $43,7 \%$ já descontada a cinza e a proteína não digerida. Para evitar a deterioração da mistura durante a hidrölise adicionou-se timolà suspensão numa concentração final de $0,05 \%$.

2.2 - Ensaios com animais

2.2.1 - Ensaios "agudos" (Fraçōes de baixo peso molecu$\operatorname{lar})$

As frações de baixo peso molecular, antes dos ensaios crónicos, foram sempre submetidas a ensaios agudos para confirma - 
ção da sua atividade sobre a tireóide.

Esses ensaios agudos foram realizados por duas metodolo gias: a) "in vivo", em experiências de $24 \mathrm{~h}$ ou b) "in vitro". No primeiro caso o material foi dado por sonda gāstrica e a captação do I 131 avaliada após 24 he com já descrito em trabalho anteri or (12). No segundo caso "in vitro", o ensaio foi conduzido usando se a tireóide isolada de ratos previamente submetidos, por 15 dias, a dieta sem iodo (dieta de caseina padrão sem iōdo na ração nà àgua de beber, conforme $\not{x} .3 .1)$.

0 método "in vitro" mostrou ser mais interessante do que o anteriormente utilizado "in vivo"(12) sob vārios aspectos: sensibilidade, diminuição do tempo de resposta da glândula, redução da quantidade de material a ser testado, diminuição do nümero de animais em cada ensaio e elirinação de interferencia de outros compostos anti-nutricionais que poderiam mascarar o efeito.

Antes de sua introdução em nossos ensaios realizamos um estudo do efeito em função da dose para avaliarmos sua vãi idade, que foi conduzido como descrito abaixo.

Animais em depleção de iodo foram decapitados com gui lhotina tomando-se o cuidado para não atingir a tireóide. A glándula foi extraída com auxilio de uma lupa e cada lóbulo colocado em um erlenmeyer de $25 \mathrm{ml}$ contendo: 4,5 $\mathrm{ml}$ de solução Krebs-Ringer-Fosfato(20) gaseificada com $95 \%$ de $\mathrm{O}_{2}$ e $5 \% \mathrm{CO}_{2}$ por meia hora e 0,3 mi de àgua destilada contendo $30{ }_{\mu} \mathrm{C} i$ de I-131. Para avaliar o efeito da dose foram adicionados ao meio de incubação 0,1, $0,2,0,3$ e $0,4 \mathrm{ml}$ da Fração Acetōnica. Cada ponto foi testado em dois animais utilizando-se um löbulo do mesmo animal como controle e o outro como experimental. 
Logo em seguida os frascos foram herméticamente fechados e levados a b.m. com agitação a $39^{\circ} \mathrm{C}$ durante $3 h$. Terminado o perĩodo, as tireóides foram lavadas com o meio de incubação e a radioatividade medida, calculando-se, em seguida, a \% de captação relativa (item $\stackrel{2}{\not \partial} .3$ a).

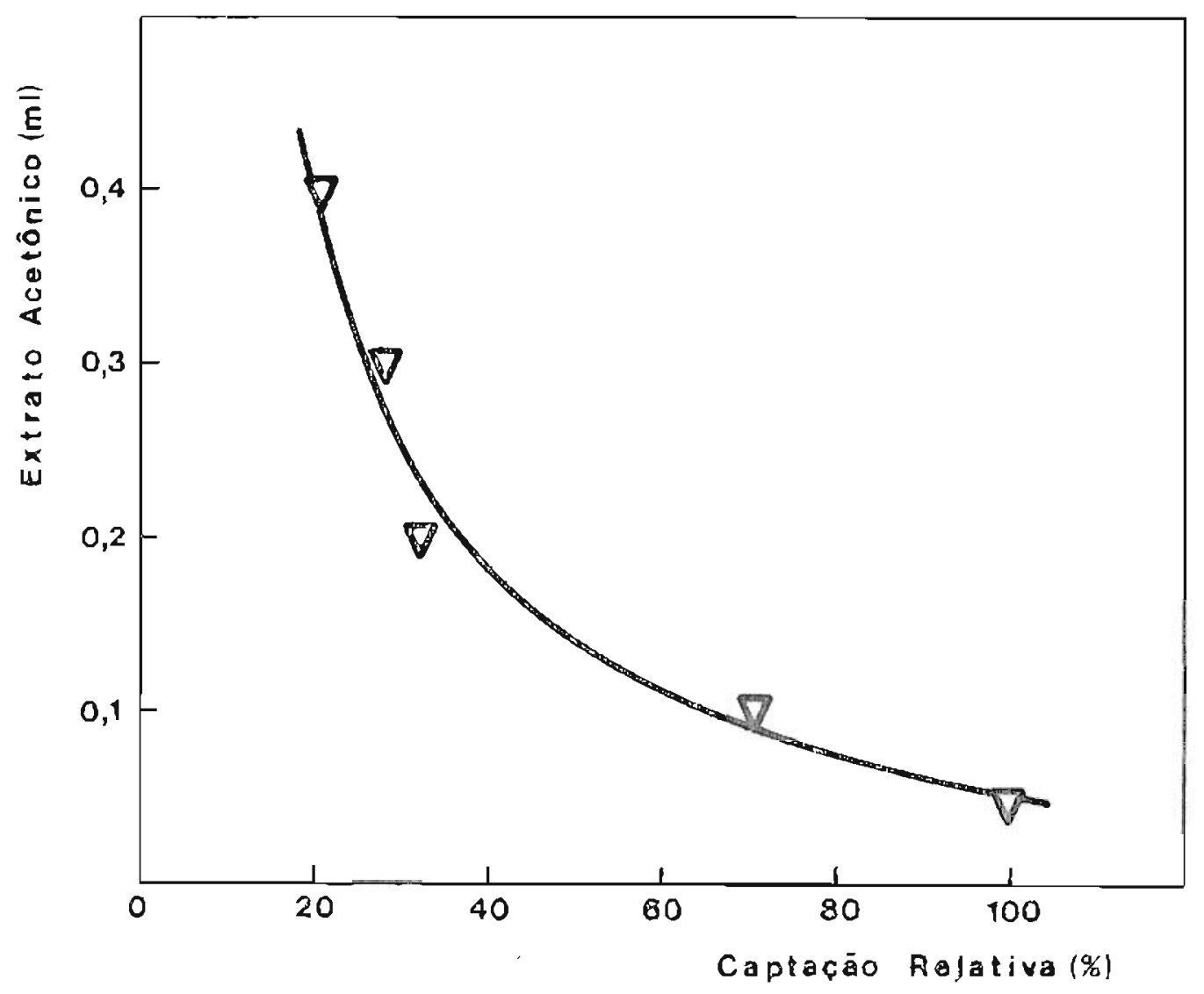

FIGURA 2 - Efeito da concentração do Extrato Acetōnico na captação de I-i31 pela tireóide

Pela Figura 2 verificamos que existe uma relação inversa não linear entre a concentração da Fração Ace tōnica e a captação relativa de I-131 pela tireóide.

A validade do método foi confirmada, tambëm, atravēs da anālise de frações que jä se mostraram ativas quando testadas nos 
ensaios de 24 hs "in vivo"(12)

No caso específico da Fração Acetōnica verificamos em mëdia uma diminuição na \% de captação em relação aos seus respectivos controles de $53 \%$ nos ensaios "in vitro" e de $37 \%$ nos ensaios "in vivo".

\subsection{2 - Ensaios com rações contendo iodo}

Foram conduzidos para se verificar a ação da Fração Ace tónica, de baixo peso molecular, em periodos de 7,18 e 57 dias. A atividade da fraça foi previamente avaliada como descrito acima.

Apös os periodos experimentais, os animais receberam I131 por via intraperitoneal nas doses de $10 \mu \mathrm{Ci} / 100 \mathrm{~g}$ de rato (nos ensaios de 7 dias) e de $5 \mu \mathrm{Ci} / 100 \mathrm{~g}$ de rato nos ensaios de 18 e 57 dias. Transcorridas 24 horas os animais foram anestesiados com ëter e o sangue retirado por punçäo cardiaca.

As tireöides e os demais ōrgãos foram removidos e logo em seguida pesados em balança analîtica. A ação da Fração Acetōnica foi determinada atravës do crescimento, consumo de ração, coe ficiente de eficācia alimentar (ganho de peso/ração ingerida) peso relativo dos órgãos, \% de captação relativa e em alguns casos, quando mostrava-se necessário, avaliou-se a distribuição dos hormō nios sēricos e na tireóide. 
2.2.3 - Ensaios usando rações com restrição de iodo

Esses ensaios foram conduzidos por tempos de 10, 14, 24 e 84 dias para estudar a ação das frações de baixo e alto peso mo lecular. A ação das primeiras foi, a exemplo do caso anterior, ve rificada atraves de ensaios agudos para se ter certeza da sua at vidade.

Os animais utilizados nessas experiēncias foram submet das à dieta de glüten sem iodo (e àgua deionizada) por dez dias para depleção e nivelamento das reservas do mineral (ver item $3.3 .2)$.

Após os periodos experimentais os animais receberam I-131 por via intraperitoneal, sendo que nos ensaios de 10,14 e 24 dias em doses de $10 \mu \mathrm{Ci} / 100 \mathrm{~g}$ de ratos e nos de 84 dias, de $5 \mu \mathrm{Ci} / \mathrm{loOg}$. Após 24 horas os animais eram anestesiados com ēter etífico, o sangue era removido por punção cardĩaca e, apōs o sacrifĩcio, as tireóides eram dissecadas, lavadas com solução fisiológica e pesa das, como os demais órgãos retirados. Nos ensaios de 84 dias $10-$ go em seguida à pesagem um dos lóbulos da tiré́ide de cada rato foi imerso em 1 ml liquido de Bouin (38) contido en tubo de ensaio de fundo chato para posterior medida de radioatividade e tratamen to histológico e histoquĩmico. A ação das diversas fraçōes era determinada através dos parāmetros jà descritos e do exame anatomopatológico da tireóide. 
2.2.4 - Ensaios com os produtos resultantes da hidrōli se enzimātica

Foram conduzidos basicamente como descrito para os casos anteriores. O tempo da experiência foi de 19 dias e a dose de $I^{131}$ de 5 HCi/loog de animal.

2.3 - Determinação da porcentagem de captação relativa

Os resultados da captação de iodo foram expressos, conforme a experiéncia, como descrito abaixo:

a) ensaios "in vitro"

$\begin{aligned} & \% \text { de captação } \\ & \text { relativa }\end{aligned}=\frac{\text { contagens do } 10 \bar{b} u l o \text { experimental }}{\text { contagens do lóbulo controle }} \times 700$

b) ensaios "in vivo"

$\begin{aligned} & \% \text { de captação } \\ & \text { relativa }\end{aligned}=-\frac{\text { contagens da tireöide }}{\text { contagens injetadas } \times \text { peso tireóide }(m g)} \times 1000$

2.4 - Dosagem dos Hormōnios da Tireóide

2.4.1 - Preparo do hidrolisado

Logo apōs a medida da radioatividade, cada tireáide foi homogeneizada conforme metodologia já descrita por koNIJN $\in$ col. (29) e adaptada por nós, da seguinte forma: a tireóide foi homogeneiza 
da com o auxílio de un homogeneizador mecānico (tipo Potter-Elvehjem) com $1 \mathrm{ml}$ de tampão Tris-HCl $0,1 \mathrm{M}$, pH 8,6 contendo $0,1 \%$ de tio uracil; $0,9 \%$ de $N a C 1$ e $0,3 \%$ de protease (Sigma P-5005): após a homogeneização acrescentaram-se mais $2 \mathrm{ml}$ de protease a $0,3 \%$ (Sigma P-5005) dissolvida no mesmo tampão.

Finda a hidrölise enzimātica em b.m. a $37^{\circ} \mathrm{C}$ por $24 \mathrm{~h}$ o hidrolisado de cada glàndula foi centrifugado a 6000 r.p.m. por 30 min e o sobrenadamente utilizado para cromatografia em camada del gada .

2.4.2 - Cromatografia dos hormōnios marcados

A separação dos hormónios e seus precursores foi realizada por cromatografia ascendente em camada delgada de silica gel $G$ de $0,25 \mathrm{~mm}$ de espessura em placas de vidro (Poligram Sil G-MA CHEREY-NAGEL) ${ }^{(53)}$.

o cromatograma de cada hidrolisado foi desenvolvido em dois sistemas de solventes distintitos a $25^{\circ} \mathrm{C}$ em uma cuba de vidro (CAMAG $10 \mathrm{~cm} \times 25 \mathrm{~cm}$ ) sem saturação prēvia.

O primeiro sistema era composto de àlcool amîlico ter ciārio: acetona: $\mathrm{NH}_{4} \mathrm{OH}(25: 8: 7)$ e o 20 sistema de álcool amîlico terciärio: acetona:0, $1 \%$ de tiossulfato de sōdio diluãdo em $\mathrm{iH}_{4} \mathrm{OH}$ $2 N(25: 8: 7)$. Antes da aplicação das amostras sobre as placas 800 ul do hidrolisado de cada gländula foram misturadas com $200 \mu$ ? de uma mistura de padrões frios $(2 \mathrm{mg}$ de $\mathrm{NaI}+4 \mathrm{mg}$ de MIT + $4 \mathrm{mg}$ OIT + $8 \mathrm{mg}$ de $\mathrm{T}_{3}$ e $8 \mathrm{mg}$ de $\mathrm{T}_{4}$ dissolvidos em $4 \mathrm{ml}$ de uma mistura $1: 1$ de $\mathrm{NH}_{4} \mathrm{OH} 2 \mathrm{~N}$ e etanol)*.

80 ul dessa mistura foram então aplicadas nas placas com

* MIT = monoiodotirosina; DIT = dijodotirosina; $T_{3}=$ triiodotironina; $T_{4}=t i-$ roxina. 
auxilio de uma micropipeta de $10 \mu 1$.

o cromatograma foi desenvolvido no lo sistema de solven tes durante 18 horas e, após a secagem em capela comventilação, colocado no 20 sistema, sendo a corrida interrompida logo após o solvente ter atingido a extremidade superior da placa laproxima damente 6 horas). Finda a corrida, os cromatogramas foram secados e revelados quimicamente. Para os compostos com grupamentos fenōlicosutilizou-se o reativo de Pauly (2l).

\subsection{3 - Medida da radioatividade dos hormônios tireoi- dianos}

Apōs revelação quîmica, os cromatogramas foram secados em estufa a $37^{\circ} \mathrm{C}$ e as manchas correspondentes a cada hormônio e seus precursores retirados da placa por raspagem; o material correspondente foi colocado em tubo de ensaio de fundo chato, para posterior contagem. Os hormônios radioativos e seus precursores foram expressos em porcentagem, relacionando-se as contagens dos 80 ul aplicados no cromatograma com aquelas correspon dentes a cada um dos hormōnios $\left(T_{3}\right.$ e $T_{4}$ ) e seus precursores (MIT e DIT).

2.5 - Dosagem dos Hormônios Séricos

Antes da remoção das tireóides os animais foram anestesiados com éter etîlico e sangue foi retirado por punção cardiá- 
ca. Após coagulação, o soro foi separado por centrifugação a 2000 r.p.m., durante 20 minutos, e congelado a $-20^{\circ} \mathrm{C}$ para poste rior anălise. A quantificaçāo dos hormōnios foi feita por radioimunoensaio avaliando-se $\mathrm{T}_{3}$ e $\mathrm{T}_{4}$ totais segundo metodologia já descrita $(7)(39)(40)$.

2.6 - Mētodos Histológicos e Histoquímicos

Nos ensaios de 84 dias as tireóides foram submetidas a exames histológicos. Um dos lóbulos da tireóide de cada animal, foi fixada em líquido de Bouin(38), incluido em parafina e sub metido a cortes de 5 micra de espessura em micrótomo rotatório American optical, modelo "820". Os cortes foram submetidos a duas técnicas de coloração: hematoxilina-eosina (HE)(44) e àcido

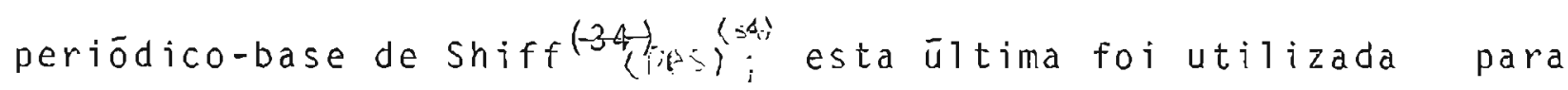
identificar o colóide (glicoproteina) existente no interior de ca da folículo.

\section{7 - Mëtodos Estatisticos}

Empregou-se basicamente o teste "ti" de student para com paração entre duas mëdias (10). 
3 - MATERIAIS

\section{$3.1-50 j a$}

Utilizamos o cultivar Sta. Rosa (Glycine max.) obtido da Estação Experimental da Escola Superior de Agronomia de Lavras, do Instituo Agronömico de Campinas ou da Cooperativa Mogiana de oleo vegetais (Comov).

$3.2-$ Animais

Foram utilizados ratos machos da linhagem Wistar Rattus norvegicus var. albinus) obtidos de colónias mantidas no Biotério da Faculdade de Ciências Farmacêticas da Universida de de são paulo e alimentados com ração comercial padrão do biotério. Durante os experimentos foram alojados em gaiolas individuais, recebendo ägua "ad-i ibitum" e os diferentes tipas de raçōes experimentais, em pō. $\quad 7$ a 8 animais foram utilizados em cada experimento e provinham de ninhadas com mesma idade. 


\section{3 - Rações Experimentais}

3.3.1 - Rações contendo iodo (Ensaios com a fração de baixo peso molecular)

Os animais dos Grupos controle e Fração Acetōnica receberam como fonte protéica caseīna a $18 \%$.

A Fração Acetōnica foi incorporada à ração de caseína na proporção de $20 \mathrm{ml}$ ou $60 \mathrm{ml} / 100 \mathrm{~g}$ conforme o caso.

os demais ingredientes: mistura vitaminica, mistura salina, celulose microcristaitina (Avicel PH 101) e öleo de milho entraram na proporção mostrada na Tabela 1. A mistura salina foi formulada segundo FOX e BRIGGS $(15)$ sem a presença de iodeto de po tássio, sendo o iodo fornecido atravēs da ägua de beber, na concen tração de $28 \mu \mathrm{gl} / 100 \mathrm{ml}$ de água, quantidade mînima necessäria para o desenvolvimento normal do animal (9). A mistura vitaminica jà descrita anteriormente ${ }^{(30)}$ sofreu algumas alterações passando a conter, por quilo: acetato de vitamina $A=0,172 \mathrm{~g}(500.000$ UI) ; vitamina $\mathrm{D}_{2}$ (calciferol) $=150.000 \mathrm{UI}$; vitamina $K_{3}=0,02 \mathrm{~g}$; ácido para-aminobenzóico $=0,1 \mathrm{~g}$; àcido L-ascörbico $=1,0 \mathrm{~g}$ e inositol $=1 \mathrm{~g}$.

3.3.2 - Rações com restrição de iodo (Ensaios com fraf̧ões de baixo ou alto peso molecular)

Os animais dos Grupos Controle, Fração Acetōnica e Ex trato Aquoso receberam, como fonte protéica, glüten. A Fração Acetônica e o Extrato Aquoso foram incorporados à ração de glūten na pro porção de $20 \mathrm{ml}$ por $100 \mathrm{~g}$ (Tabela 2). Os demais produtos de fracionamen to da soja: Farinha Desengordurada e Autoclavada, Residuo da Exira ção com Agua, Resíduo Metanol-Acetona, Hidrolisado e Residuo da Hidrōilse foram incorporados de forma a se obter uma concentra- 
ção final próxima de $18 \%$ de proteîna.

As rações preparadas exclusivamente com proteîna de soja foram suplementadas com $D L$-metionina $(0,2 \%$ na ração) e as de glüten com L-1 isina $(0,6 \%$ na ração) (Tabela 2 ).

Os outros componentes da ração: mistura vitamĩnica (item 2.3.1), mistura salina(15) e öleo de milho foram os mesmos da ração com iodo e acrescentadas nas concentações de 1,4 e $8 \%$ respectivamente. Nesse caso a āgua de beber, alēm da mistura salina, não continha iodo, sendo destilada e deionizada.

A quantidade de celulose acrescentada às rações estava na dependēncia da quantidade de fibra prēexistente na soja, perfa zendo uma concentração final de $5 \%$; apenas no caso dos produtos da hidrólise a concentração final foi diferente $(7,8 \%)$.

Dez dias antes do inicio das experiências de 10, 14 e 24 dias de duração, os animais foram alimentados com dieta contro le de Giūten (18\% de proteina).

Nesse caso, tambēm, tanto a āgua de beber (deionizada) bem como a mistura salina não continham jodo, para permitir um nivelamento inicial das reservas de iodo na tireöide.

As rações experimentais de todos os grupos com e sem iodo eram acrescidas de amido de milho em uma quantidade suficien te para perfazer um total final de 100 gramas.

o teor final de proteina foi obtido por anālise( 2 ), ve rificando-se que todas as raçóes estavam dentro dos limites esperados de $18 \% \pm 0,8$. Os fatores de conversão utilizados para a caseîna, soja e glüten foram respectivamente de 6,$25 ; 5,71$ e 5,70. 
TABELA 1 - Composição básica das rações contendo iodo

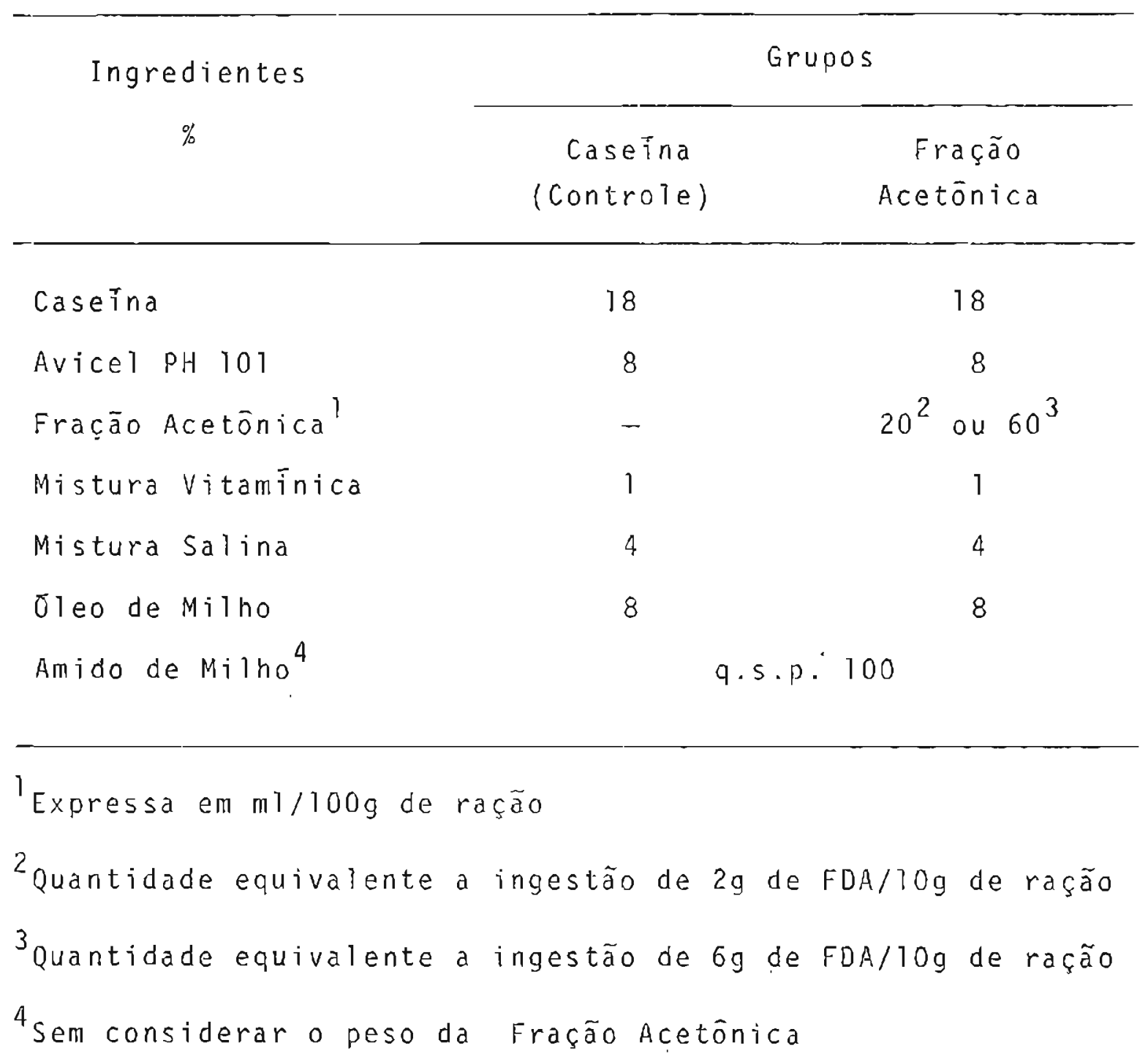


TABELA 2 - Composição bäsica das rações com restrição em iodo ${ }^{1}$

\begin{tabular}{|c|c|c|c|c|c|c|c|c|}
\hline \multirow{2}{*}{ Ingredientes $(\%)$} & \multicolumn{8}{|c|}{ G $r u p \quad o s$} \\
\hline & $\begin{array}{c}\text { Glūten } \\
\text { (Controle) }\end{array}$ & $F D A^{2}$ & $\begin{array}{c}\text { Fraçāo } \\
\text { Acetônica }\end{array}$ & $\begin{array}{l}\text { Extrato } \\
\text { Aquoso }\end{array}$ & $\begin{array}{l}\text { Residuo } \\
\text { Extração } \\
\text { c/Ägua }\end{array}$ & $\begin{array}{l}\text { Residuo } \\
\text { Metanol } \\
\text { Acetona }\end{array}$ & $\begin{array}{l}\text { Hidrol } \underline{\mathrm{j}} \\
\text { sado }\end{array}$ & $\begin{array}{l}\text { Resíduo } \\
\text { da Hi- } \\
\text { drolise }\end{array}$ \\
\hline Glüten & 18 & - & 18 & 18 & - & - & - & 13,8 \\
\hline Proteina de Soja & - & 18 & - & - & 78 & 18 & 18 & 4,2 \\
\hline Extrato Aquoso 3 & - & - & - & 20 & - & - & - & - \\
\hline Fração Acetônica ${ }^{3}$ & - & - & 20 & - & - & - & - & - \\
\hline Avicel PH 101 & 5 & 2,5 & 5 & 5 & 2,5 & 2,5 & 7,8 & - \\
\hline L-Lisina & 0,6 & - & 0,6 & 0,6 & - & - & - & 0,6 \\
\hline OL-Metionina & - & 0,2 & - & - & 0,2 & 0,2 & 0,2 & - \\
\hline
\end{tabular}

'A mistura salina, mistura vitaminica e óleo de milho foram inclutidos na $\%$ de 4 , 1 e 8 , e o amido de milho na quantidade suficiente para completar 100 , sem considerar o peso do Extrato Aquoso e Fração Acetônica.

${ }^{2}$ Farinha Desengordurada e Autoclavada.

3 Expressa em mi]/100g de ração. 


\section{4 - Iodo radioativo}

Utilizou-se iodeto de sōdio (Na ${ }^{131}$ I) produzido peros la boratōrios da Divisão de Radioisōtopos da Comissão Nacional de Energia Nuclear - São Paulo, isento de carregador, dissolvido em solução fisiológica.

As contagens foram efetuadas num detetor de cintilação com cristal de poço de iodeto de sódio ativado com tālio NaI(Ti) e contador modelo Ultra Scaler (Nuclear Chicago).

o giúten e a caseỉna foram obtidas no comércio local e tinham respectivamente 71,1 e $81,0 \%$ de proteina. Todos os outros reagentes usados foram de grau PA, Merck ou Sigma. 
4 - RESULTADOS E DISCUSSATO

A 1 iteratura tem mostrado que existe divergēncia em relação à magnitude da ação da soja crua ou de seus produtos sobre a tireöide de humanos ou animais. Essa divergēncia, que difí culta a interpretação do significado biológico da ação da soja, é acentuada pelas variações dos tempos experimentais utilizados pelos autores, pelos tipos de produtos e, principalmente, pelos diferentes teores de iodo nas rações experimentais testadas.

SHARPLESS e col.(54), WILGUS e col. (64) e HALVERSON e col. (18) demonstraram, em ratos e galinhas, que a inclusão de soja não processada na ração, era capaz de provocar um aumento da tireóide e que essa propriedade era inibida, totalmente, pela administração de quantidades elevadas de iodo, ou parcialmente, pe10 tratamento térmico.

Estudos posteriores $(4)$ em ratos alimentados com farinha de soja crua ou processada, proteína isolada e leite de soja, parecem confirmar essas observações: a adição de $160 \mu \mathrm{g}$ de $\mathrm{I} / 100 \mathrm{~g}$ de ração foi suficiente para a glândula voltar ao seu peso normal. Alguns autores $(19)(45)(55)(63)$ observaram, em crianças alimentadas com leite de soja, não suplementado com iodo. a formação de bōcio. Por outro lado, MCCARRISON (35) observou que teores de iodo bem superiores ao necessärio (1,5 mg I/dia) não 
eram suficientes para curar a hiperplasia provocada pela soja. Contudo é oportuno comentar que o böcio tratado com excessivas quantidades de iodo pode causar tireotoxicosis (41).

segundo SUWA e col. (58) a adição 20 is $\mathrm{I} / 10 \mathrm{~g}$ na ração não foram suficientes para curar o böcio desencadeado por derivados de soja (queijo de soja), porém, essa quantidade foi suficiente para reverter o bócio causado por dietas pobres em iodo.

Em trabalho anterior ${ }^{(12)}$ conseguimos isolar parcialmente um fator ativo em ensaios de $24 \mathrm{~h}$. Esse fator foi no presente trabaTho estudado, não apenas em ensaios agudos mas em rações, por tem pos mais longos, e em condiçōes de restrição ou não de iodo na raÇão.

4.1 - Ensaios com Rações Contendo Iodo. Efeito da Fração Ace tōnica

Os teores aproximados de iodo presentes nas raçōes que uti lizamos em nossos ensaios foram de $4,3 \mathrm{\mu g} l / 10 \mathrm{~g}$ de ração, prōximos daqueles considerados ótimos para o desenvolvimento normal do rato $(2,8 \mu g \mathrm{l} / \mathrm{log} \operatorname{ração})(9)$. A caseína fornecia em torno de $0,67 \mu g$ de $I / 10 g$ de ração e a àgua de beber $3,61 \mu g$ I/13g de ägua (a cada $10 \mathrm{~g}$ de ração o animal ingere aproximadamente $13 \mathrm{~g}$ de ãgua). Ainda a duração dos ensaios foi variāvel, uma vez que o fator tempo poderia influir nas respostas da gländula frente a um deter minado estīmulo.

A fração (Fração Acetônica) estudada nesse caso foi par cialmente purificada $(3-1-2$ e Figura 1$)$ e composta por produtos de baixo peso molecular, já que boa parte das proteínas (inclusi- 
ve fitohemaglutininas e antitripsina) foram eliminadas pelo aquecimento, pela precipitação isoelétrica em pH 4,2 e numa, segunda fase, pelo tratamento com acetona(32)(37). Essa fração mostrou-se ativa em ensaios de 24 hs e composta principalmente de peptidios, glîcides e flavonóides(12).

E importante lembrar que ela foi obtida a partir de soja autoclavada por 30 minutos e que a sua atividade se mantinha mesmo após autoclavagem a $121^{\circ} \mathrm{C}$ por $1 \mathrm{~h}$.

A experiēncia foi conduzida por 7,18 e 57 dias não se verificando diferenças significativas nos indices de crescimento e coeficiente de eficácia alimentar (CEA).

Apenas os pesos relativos do rim determinados nos ensaios de 7 dias (concentração tripla da Fração Acetōnica) e 57 dias, sofreram um aumento significativo respectivamente de $15,9 \%$ e $13,1 \%$ (Tabela 3$)$.

Com relação aos parânetros da tireōide, na experiência de 7 dias de duração, só observamos diferença significativa para

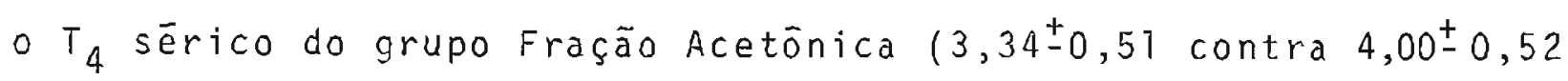
ug/dl para o controle). Por outro lado para tempos mais longos (18 dias) o $T_{4}$ sērico não mostrou mais diferença, a mesmo acontecendo aos 57 dias. Verificou-se, porém, uma diminuição na porcenta gem de captação relativa, na relação $T_{3} / T_{4}$ e um aumento da \% MIT e da relação MIT/DIT (Tabela 4). Nas experiēncias de 57 dias as únicas alterações observadas foram aumento da \% DIT e diminuição de $\mathrm{T}_{3}$.

Os efeitos observados a nĩvel glāndular e sérico não fọ ram suficientes para desencadear um aumento no peso da glândula e mesmo apōs um período de 57 dias verificamos que o comportamen 
TABELA 3 - Efeito da fração acetōnica sobre o crescimento e peso de órgãos. Rações contendo iodol,2

\begin{tabular}{|c|c|c|c|c|c|c|c|}
\hline \multirow{2}{*}{ Grupos } & \multirow{2}{*}{ Dias } & \multicolumn{2}{|c|}{ Peso rato (g) } & \multirow{2}{*}{$\begin{array}{c}\text { Ração } \\
\text { ingerida } \\
(g)\end{array}$} & \multicolumn{3}{|c|}{ Peso $/ 100 \mathrm{~g}$ rato } \\
\hline & & Inicial & Final & & $\begin{array}{c}\text { Tireóide } \\
\text { mg }\end{array}$ & $\begin{array}{c}\text { Fígado } \\
\text { g }\end{array}$ & $\begin{array}{c}\mathrm{R} \\
\mathrm{g}\end{array}$ \\
\hline Caseina & 7 & $\begin{array}{r}6 \overline{1,4} \\
+\quad 5,5\end{array}$ & $\begin{array}{l}106,2 \\
\div \quad 10,0^{a}\end{array}$ & $\begin{array}{r}92,3 \\
+\quad 6,7\end{array}$ & $\begin{array}{r}10,97 \\
\pm \quad 2,57\end{array}$ & $N D^{3}$ & ND \\
\hline $\begin{array}{l}\text { Fração Acetōnica } \\
(20 \mathrm{~m} i \mathrm{~g} / 100 \mathrm{~g}\end{array}$ & 7 & $\begin{array}{r}61,6 \\
\pm \quad 4,6\end{array}$ & $\pm^{703,8} 8,1 \mathrm{a}$ & $\begin{array}{r}92,5 \\
+\quad 6,7\end{array}$ & $\begin{array}{r}9,63 \\
\pm \quad 1,14^{\mathrm{a}}\end{array}$ & ND & $\mathrm{ND}$ \\
\hline Caseina & 7 & $\begin{array}{r}65,9 \\
\pm \quad 3,8\end{array}$ & $\begin{array}{r}108,9 \\
\pm \quad 7,8\end{array}$ & $\begin{array}{r}106,1 \\
-\quad 4,7\end{array}$ & $\begin{array}{r}10,29 \\
\pm \quad 1,51\end{array}$ & $\begin{array}{r}4,54 \\
-0,33\end{array}$ & $\begin{array}{r}0,88 \\
+0,05\end{array}$ \\
\hline $\begin{array}{l}\text { Fração Acetōnica } \\
(60 \mathrm{ml} / 100 \mathrm{~g})\end{array}$ & 7 & $\begin{array}{r}65,1 \\
\pm \quad 4,7\end{array}$ & $\begin{array}{r}107,2 \\
\pm \quad 6,0\end{array}$ & $\begin{array}{r}109,5 \\
\pm \quad 7,3\end{array}$ & $\begin{array}{l}9,10 \\
+\quad 1,10^{a}\end{array}$ & $\begin{array}{l}4,92 \\
\pm 0,66\end{array}$ & $+\begin{array}{l}1,02 \\
-0,06\end{array}$ \\
\hline Caseĩna & 18 & $\begin{array}{r}84,6 \\
\pm \quad 7,0\end{array}$ & $\begin{array}{r}182,6 \\
\pm \quad 12,2\end{array}$ & $\begin{array}{r}314,8 \\
\pm \quad 16,4^{a}\end{array}$ & $\begin{array}{r}5,14 \\
\pm \quad 0,99^{\mathrm{a}}\end{array}$ & ND & NO \\
\hline Fração Acetōnica & 18 & $\begin{array}{r}84,0 \\
\pm \quad 6,8\end{array}$ & $\begin{array}{l}178,2 \\
\pm \quad 10,3\end{array}$ & $\pm \quad 313,4 \mathrm{a}$ & $\begin{array}{r}6,06 \\
+\quad 1,15^{\mathrm{a}}\end{array}$ & ND & ND \\
\hline Case ina & 57 & $\begin{array}{r}36,7 \\
\pm \quad 1,4\end{array}$ & $\begin{array}{r}237,1 \\
\pm \quad 15,0^{a}\end{array}$ & $\begin{array}{r}634,1 \\
\pm \quad 37,0^{a}\end{array}$ & $\begin{array}{r}10,95 \\
+\quad 2,39^{\mathrm{a}}\end{array}$ & $\begin{array}{l}3,27 \\
\pm 0,36\end{array}$ & $\pm \begin{array}{r}0,61 \\
-0,03\end{array}$ \\
\hline Fração Acetônica & 57 & $\begin{array}{r}36,4 \\
\pm \quad 1,4\end{array}$ & $\begin{array}{r}242,4 \\
\pm \quad 13,7 a\end{array}$ & $\begin{array}{r}669,7 \\
+\quad 42,2^{a}\end{array}$ & $\begin{array}{r}11,12 \\
+\quad 1,97^{a}\end{array}$ & $\begin{array}{r}3,15 \\
+0,26 \\
\end{array}$ & $\begin{aligned} & 0,69 \\
&+0,05\end{aligned}$ \\
\hline
\end{tabular}

Mëdia e Desvio Padräo

${ }^{2}$ Letras iguais jndicam que não houve diferença significativa $(P>0,05)$

$3_{\text {Não determinado }}$ 
TABELA 4 - Efeito da fração acetōnica sobre a tịeōide. Raçōes contendo iódo ${ }^{1,2}$.

\begin{tabular}{|c|c|c|c|c|c|c|c|c|}
\hline Grupos & Dias & $\begin{array}{l}\text { \% captaçäo } \\
\text { relativa }\end{array}$ & $\%$ MIT & $\%$ DIT & $\% \mathrm{~T}_{3}$ & $\% \mathrm{~T}_{4}$ & MIT / O IT & $T_{3} / T_{4}$ \\
\hline Caseina & 7 & $+\begin{array}{l}8,54 \\
-1,69\end{array}$ & $\begin{array}{r}20,25 \\
+\quad 1,88\end{array}$ & $\begin{array}{r}36,99 \\
\pm \quad 3,72^{a}\end{array}$ & $\begin{aligned} 2,04 \\
-0,41\end{aligned}$ & $\begin{array}{r}14,39 \\
\pm \quad 4,45\end{array}$ & $\pm 0,55$ & $\pm^{0,14}$ \\
\hline $\begin{array}{l}\text { Fração Acetōnica } \\
(20 \mathrm{~m} 1 / 100 \mathrm{~g})\end{array}$ & 7 & $\begin{array}{r}7,78 \\
\pm 0,90^{a}\end{array}$ & $+\begin{array}{r}20,72 \\
+\quad 1,66\end{array}$ & $\begin{array}{r}38,15 \\
+\quad 3,50^{a}\end{array}$ & $\begin{array}{l}1,88 \\
\pm 0,82\end{array}$ & $\begin{array}{r}13,19 \\
+\quad 5,22^{\mathrm{a}}\end{array}$ & $\begin{array}{l}0,54 \\
+0,04\end{array}$ & $\begin{array}{r}0,15 \\
\pm 0,08^{a}\end{array}$ \\
\hline Caseĩna & 7 & $\begin{array}{r}5,03 \\
\pm 1,37\end{array}$ & $\begin{array}{r}23,33 \\
\pm \quad 2,75\end{array}$ & $\begin{array}{r}40,21 \\
+\quad 3,92\end{array}$ & $\begin{aligned} & 3,18 \\
\pm & 0,54\end{aligned}$ & $\begin{array}{r}17,65 \\
+\quad 4,23^{a}\end{array}$ & $\begin{array}{l}0,58 \\
+0,03\end{array}$ & $\pm_{-0,02}^{0,18}$ \\
\hline $\begin{array}{l}\text { Fração Acetônica } \\
(60 \mathrm{ml} / 100 \mathrm{~g})\end{array}$ & 7 & $\begin{array}{r}5,75 \\
\pm 0,88\end{array}$ & $\pm \begin{array}{r}21,35 \\
\pm \quad 1,23\end{array}$ & $\begin{array}{r}38,23 \\
\pm \quad 2,56\end{array}$ & $\begin{array}{r}3,59 \\
+0,38\end{array}$ & $\begin{array}{r}20,62 \\
\pm \quad 2,06\end{array}$ & $\begin{array}{r}0,56 \\
+0,03\end{array}$ & $\begin{array}{r}0,77 \\
+0,02\end{array}$ \\
\hline Caseina & 18 & $\begin{array}{r}18,54 \\
+\quad 4,90^{\mathrm{a}}\end{array}$ & $\begin{array}{r}17,76 \\
\pm \quad 2,42^{a}\end{array}$ & $\pm^{37,75} 3,49^{a}$ & $\begin{array}{r}1,67 \\
\pm 0,29 \mathrm{a}\end{array}$ & $\begin{array}{r}9,42 \\
\pm 2,07\end{array}$ & $\begin{array}{l}0,47 \\
\pm 0,04\end{array}$ & $\begin{aligned} & 0,78 \\
& \pm 0,03^{a}\end{aligned}$ \\
\hline Fração Acetônica & 18 & $\begin{array}{l}11,00 \mathrm{~b} \\
\pm \quad 1,54\end{array}$ & $\begin{array}{r}20,11 \mathrm{~b} \\
\pm \quad 1,80^{\circ}\end{array}$ & $\begin{array}{r}37,23 \\
+\quad 2,26\end{array}$ & $\begin{array}{r}1,57 \\
\pm 0,41\end{array}$ & $\begin{array}{r}1], 69 \\
\pm \quad 3,86\end{array}$ & $\begin{array}{l}0,54 \mathrm{~b} \\
\pm 0,03\end{array}$ & $\pm^{0,14} \mathrm{~b}$ \\
\hline Caseina & 57 & $\begin{array}{r}6,85 \\
\pm \quad 2,02\end{array}$ & $\begin{array}{r}21,67 \\
-2,30^{a}\end{array}$ & $\begin{array}{r}39,12 a \\
\pm 4,519\end{array}$ & $\pm^{0,62}+13^{a}$ & $\begin{array}{l}7,81 \\
\pm 0,99^{2}\end{array}$ & $\begin{array}{l}0,56 \\
\pm 0,11\end{array}$ & $\begin{array}{l}0,40 \\
+0,13^{a}\end{array}$ \\
\hline Fração Acetônica & 57 & $\begin{array}{r}7,84 \\
\pm \quad 2,34^{\mathrm{a}}\end{array}$ & $\begin{array}{r}27,94 \mathrm{a} \\
+0,89^{\mathrm{a}}\end{array}$ & $\begin{array}{r}43,53 \mathrm{~b} \\
\pm \quad 3,47\end{array}$ & $\Psi_{-0,46}^{0,46}$ & $\begin{array}{l}1,15 \\
\pm 0,32^{2}\end{array}$ & $\pm^{0,50}, 05^{\mathrm{a}}$ & $\begin{aligned} 0,41 \\
-0,10^{\circ}\end{aligned}$ \\
\hline
\end{tabular}

1 Média e Desvio Padrão

Letras iguais indican que não houve diferença significativa $(P>0,05)$ 
to da tireóide do grupo Fraçăo Acetónica foi praticamente igual ao seu Controle.

Uma vez que a Fração Acetõnica mostrou-se ativa quando testada em tireóides isoladas e em ensaios "in vivo" de $24 h s$, era de se esperar que pelo menos nos ensaios de 57 dias ela provocas se um aumento no peso da gländula, o que porēm, não ocorreu.

E possível que a concentração do fator ativo, quando ensaiado na presença da ração, deva ser superior para que uma ação se faça detectāvel. A presença da ração pode alterar a absorção e o metabolismo do fator, ou mesmo liga-lo, de forma a torna-lo menos eficiente. Outra explicação poderia estar ligada ao teor normal de iodo na ração. Em vista desta segunda possibilidade conduzimos ensaios semelhantes, mas agora em situação de restrição de iodo. Nessas condições foram estudadas tanto as frações de baixo como, posteriormente, as de alto peso molecular.

\section{2 - Ensaios com Rações com Restrição de Iodo}

Para esses ensaios eliminamos o iodo da mistura salina e fornecendo-se aos animais àgua destilada e deionizada. Além disso nos ensaios de fraçōes de baixo peso molecular substituiu-se a fonte proteica caseina (mais rica em iodo) pelo glúten suplementado com lisina. Nos estudos das frações de alto peso motecular utilizou-se o glūten suplementado, como controle e, nos grupos expe rimentais, utilizou-se a prōpria proteina de soja (suplementada com metionina) presente nos produtos de fracionamento.

A suplementação com lisina ou metionina conforme o caso foi necessäria para garantir um crescimento homogênéo, principalmente 
nas experiências com fraçôes de alto peso molecular, onde tinhamos duas fontes de proteina distintas, uma para o grupo controle e outra para os experimentais.

4.2.1 - Efeito das fraçöes de baixo peso molecular

Os efeitos da Fração Acetōnica nesse caso (restrição em iodo) foram estudadas em ensaios de 10,24 e 84 dias.

Nos ensaios de 84 dias, por razões de dificuldades de pre paração no laboratōrio, a Fração Acetōnica foi substituída pelo Extrato Aquoso (fase anterior da purificação). Testes anterior mente realizados em ensaios de 24 hs "in vivo"(12) e com tireöide iso ladas mostraram um comportamento semeihante entre esses dois produtos de fracionamento da soja, permitindo essa substituição.

Nos trēs ensaios realizados não foi constatada nenhuma diferença significativa no peso final e na quantidade de ração in gerida (Tabela 5). Nos experimentos de 84 dias não observamos ne nhuma variaçăo no coeficiente de eficăcia alimentar, apenas, a digestibilidade aparente determinada na ültima semana do ensaio, do grupo experimental $(91,7 \% \pm 1,05)$ foi estatisticamente menor em relação ao grupo controle $(93,8 \pm 0,37)$ (Tabela 5). Nas determinações de peso relativo dos órgãos sō verificamos um aumento no peso da tireóide nos ensaios de 10 dias.

Com relação aos efeitos sobre a tireóide, nos trés perĩodos experimentais conduzidos, sō observamos uma diminuição na porcentagem de captação relativa, nos ensaios de 10 dias. Por ou tro lado, as determinaçōes dos hormōnios e seus precursores a nivel glāndular e suas relações (MIT/DIT e $T_{3} / T_{4}$ ) não evidencjaram 
TABELA 5 - Efeito das frações de baixo peso molecular sobre o crescimento e peso de ōrgãos. Rações com restrição em iodo ${ }^{\dagger}, 2$

\begin{tabular}{|c|c|c|c|c|c|c|c|c|}
\hline \multirow{2}{*}{ Grupos } & \multirow{2}{*}{ Dias } & \multicolumn{2}{|c|}{ Peso rato $(g)$} & \multirow{2}{*}{$\begin{array}{l}\text { Raçäo } \\
\text { ingerida } \\
(g)\end{array}$} & \multicolumn{4}{|c|}{ peso/loog rato } \\
\hline & & Inicial & Final & & $\begin{array}{c}\text { Tireōide } \\
\text { mg }\end{array}$ & $\underset{g}{F \mathfrak{T} \text { gado }}$ & $\begin{array}{c}\text { Baço } \\
g\end{array}$ & $\begin{array}{c}\mathrm{Rim} \\
9\end{array}$ \\
\hline \multirow[t]{2}{*}{ Giuten } & \multirow[t]{2}{*}{10} & 109,0 & 770,0 & 178,8 & 7,58 & \multirow[t]{2}{*}{ ND } & \multirow[t]{2}{*}{ No } & \multirow[t]{2}{*}{ ND } \\
\hline & & $\pm \quad 4,2$ & $\pm 6,5^{\mathrm{a}}$ & $\pm 9,9^{\mathrm{a}}$ & $\pm 1,15^{\mathrm{a}}$ & & & \\
\hline \multirow[t]{2}{*}{ Fração Acetōnica } & \multirow[t]{2}{*}{10} & 109,2 & 169,6 & 180,7 & 8,95 & \multirow[t]{2}{*}{ No } & \multirow[t]{2}{*}{ ND } & \multirow[t]{2}{*}{$N D$} \\
\hline & & $\pm 3,4$ & $\pm 7,5^{a}$ & $\pm 12,0^{a}$ & $\pm 1,26^{b}$ & & & \\
\hline \multirow[t]{2}{*}{ G1 üten } & \multirow[t]{2}{*}{24} & 68,4 & 171,1 & 314,0 & 8,86 & 4,36 & 0,30 & 0,81 \\
\hline & & $\pm \quad 6,8$ & $\pm 14,0^{\tilde{a}}$ & $\pm 28,8^{\mathrm{a}}$ & $\pm 0,86^{a}$ & $\pm 0,57^{\mathrm{a}}$ & $\pm 0,07^{a}$ & $\pm 0,06^{a}$ \\
\hline \multirow[t]{2}{*}{ Fração Acetōnica } & \multirow[t]{2}{*}{24} & 67,5 & 161,9 & 305,8 & 8,34 & 4,17 & 0,30 & 0,80 \\
\hline & & $\pm \quad 6,3$ & $\pm 16.6^{\mathrm{a}}$ & $\pm 13,6^{\mathrm{a}}$ & $\pm 1,12^{a}$ & $\pm 0,35^{a}$ & $\pm 0,05^{\mathrm{a}}$ & $\pm 0,09^{a}$ \\
\hline \multirow[t]{2}{*}{ Gluten } & \multirow[t]{2}{*}{84} & 45,4 & 288,6 & 1194,6 & 10,44 & 3,43 & 0,19 & 0,65 \\
\hline & & $\pm \quad 4,8$ & $\pm 42,0^{\mathrm{a}}$ & $\pm 111,3^{\mathrm{a}}$ & $\pm 1,99^{\mathrm{a}}$ & $\pm 0,19^{\mathrm{a}}$ & $\pm 0,02^{\mathrm{a}}$ & $\pm 0,04^{a}$ \\
\hline \multirow[t]{2}{*}{ Extrato Aquoso } & \multirow[t]{2}{*}{84} & 44,8 & 280,8 & 1257,1 & 10,05 & 3,37 & 0,21 & 0,67 \\
\hline & & $\pm \quad 4,1$ & $\pm 31,4^{a}$ & $\pm 105,2^{\mathrm{a}}$ & $\pm 1,26^{\mathrm{a}}$ & $\stackrel{ \pm}{ \pm} 0,22^{a}$ & $\pm 0,03^{a}$ & $\pm 0,05^{a}$ \\
\hline
\end{tabular}

TMëdia e Desvio Padrão

${ }^{2}$ Letras iguats indicam que näo houve diferença significativa $(P>0,05)$ 
TABELA 6 - Efeito das fraçöes de baixo peso molecular sobre a tireóide. Rações com restrição em iodo $0^{7,2}$.

\begin{tabular}{|c|c|c|c|c|c|c|c|c|}
\hline Grupos & Dias & $\begin{array}{l}\text { \% Captação } \\
\text { relativa }\end{array}$ & $\%$ MIT & $\%$ DIT & $\% \mathrm{~T}_{3}$ & $\% T_{4}$ & MIT/DIT & $T_{3} / T_{4}$ \\
\hline Glüten & 10 & $\begin{array}{r}11,17 \\
\pm \quad 1,44^{\mathrm{a}}\end{array}$ & $\begin{array}{l}21,23 \\
+\quad 3,22^{\mathrm{a}}\end{array}$ & $\begin{array}{r}39,08 \\
\pm \quad 5,86^{2}\end{array}$ & $\begin{array}{c}2,21 \\
\pm 0,73^{a}\end{array}$ & $\begin{array}{r}16,70 \\
+\quad 5,06^{\mathrm{a}}\end{array}$ & $\begin{array}{c}0,55 \\
\pm 0,11^{\mathrm{a}}\end{array}$ & $\begin{array}{c}0,13 \\
+0,07^{a}\end{array}$ \\
\hline Fração Acetônica & 10 & $\begin{aligned} & 9,22 \\
\pm & 0,56^{b}\end{aligned}$ & $\begin{array}{r}18,65 \\
+\quad 2,23^{a}\end{array}$ & $\begin{array}{r}37,56 \\
\pm \quad 4,84^{\mathrm{a}}\end{array}$ & $\begin{array}{c}2,21 \\
\pm 0,52^{a}\end{array}$ & $\begin{array}{r}17,48 \\
\pm \quad 3,55^{\mathrm{a}}\end{array}$ & $\begin{array}{c}0,50 \\
\pm 0,08^{a}\end{array}$ & $\begin{array}{c}0,12 \\
\pm 0,01^{a}\end{array}$ \\
\hline Glüten & 24 & $\begin{array}{l}6,74 \\
\div \quad 0,87^{a}\end{array}$ & ND & ND & ND & ND & MD & ND \\
\hline Fração Acetônica & 24 & $\begin{array}{r}7,61 \\
+\quad 1,08^{\mathrm{a}}\end{array}$ & MD & ND & MD & ND & ND & ND \\
\hline Giüten & 84 & $\begin{array}{r}15,91 \\
+\quad 2,40^{\mathrm{a}}\end{array}$ & $\begin{array}{r}29,17 \\
\pm \quad 1,58^{\mathrm{a}}\end{array}$ & $\begin{array}{r}40,67 \\
\pm \quad 2,86^{\mathrm{a}}\end{array}$ & $\begin{array}{c}1,06 \\
\pm 0,35^{a}\end{array}$ & $\begin{array}{c}9,33 \\
\pm 4,54^{\text {a }}\end{array}$ & $\begin{array}{c}0,72 \\
\pm 0,04^{\mathrm{a}}\end{array}$ & $\begin{array}{c}0,12 \\
\pm 0,03^{\mathrm{a}}\end{array}$ \\
\hline Extrato Aquoso & 84 & $\begin{array}{r}15,80 \\
\pm \quad 2,00^{\mathrm{a}}\end{array}$ & $\begin{array}{l}28,00 \\
+\quad 1,68^{\mathrm{a}}\end{array}$ & $\begin{array}{r}40,06 \\
+\quad 2,50^{a}\end{array}$ & $\begin{array}{c}1,19 \\
\pm 0,54\end{array}$ & $\begin{array}{r}10,35 \\
\pm \quad 5,21^{\mathrm{a}}\end{array}$ & $\begin{array}{c}0,70 \\
+0,07^{\mathrm{a}}\end{array}$ & $\begin{array}{c}0,12 \\
\pm 0,02^{a}\end{array}$ \\
\hline
\end{tabular}

TMëdia e Desvio Padrão

${ }^{2}$ Letras iguais indicam que não houve diferença significativa $(P>0,05)$ 
nenhuma variação significativa (Tabela 6).

Pelos resultados aqui abtidos, com as frações de baixo peso molecular incorporadas em rações com e sem iodo, concluímos que o fator nelas presente, apesar de se mostrar ativo em ensaios "in vitro" e anteriormente "in vivo"(12), ou não é suficien temente ativo ou está em uma concentração relativamente baixa. A glāndula, em ambos os casos, aparentenente conseguiu apōs um determinado periodo equilibrar e superar qualquer efeito nela causado. Os nossos resultados se opōem aos de KONIJN e col. (28), segundo os quais frações semelhantes à nossa, porēm, obtidas de soja crua, quando incorporadas à rações de farinha de soja tostada, aumentavam a capacidade de ligação das proteinas do soro de rato pelo $T_{3}$ exōgeno radioativo jä a partir de 10 dias.

Nesse caso podemos dizer, tambēm, que a quantidade de fator presente nessas frações talvez esteja relecionada com a variedade da soja analisada.

\subsection{2 - Efejto das frações de alto peso molecular}

A partir de dados anteriores de nosso laboratório e, com base na literatura, resolvemos verificar a possivel existencia de outro tipo de fator, associado à fração protéica de alto peso molecular e não extraîvel com āgua ou solventes orgānicos. Foram assim realizadas 3 experiências: a la. por um período de 10 dias, em que testamos a FDA e o Resĩduo Aquoso e a $2 a$. en que testamos novamente a FDA e um residuo mais purificado, o Residuo Metanol-Acetona, por 74 dias. A $3 a$. experiência foi realizada em fun ção dos resultados da la e 2a; como verificamos que ambos 
os resĩduos testados provocavam praticamente o mesmo efeito na glāndula, estudamos o efeito de apenas um deles, o Resíduo Extra. ção com Agua por um perĩodo mais longo, de 84 dias.

Nos 3 ensaios estudados não observamos nenhuma alteração no peso final e ração ingerida (Tabela 7).

Nos ensaios de 84 dias porém conseguimos detectar uma diminuição significativa na digestibilidade aparente do grupo expe rimental $(86,38 \pm 1,69)$ em relação ao grupo controle $(93,22 \pm 0,56)$; por sua vez, o indice de Coeficiente de Eficácia Alimentar do gru po Resĩduo Extração com Ãgua tambēm mostrou uma diminuição de $10 \%$, em relação a o seu controle sendo respectivamente iguais a $0,18 \pm 0,01$ e $0,20 \pm 0,01$.

os pesos relativos da tireóide dos grupos experimentais mostraram, em todos os casos, um aumento significativo em relação aos seus respectivos controles (Tabela 7 ).

Nos ensaios de 10 dias o aumento foi de $32,5 \%$ para o grupo que recebeu FDA e $28,6 \%$ para o grupo que recebeu Resíduo Extração com Agua. Nos ensaios de 14 dias o aumento foi de $36,8 \%$ e $34,4 \%$ respectivamente para o grupo FDA e Residuo Metanol-Acetona. Finalmerte nos ensaios de 84 dias de Residuo Extração com Ägua mostrou um aumento de $40,1 \%$ en relação ao controle.

Esses resultados estão em parte de acordo com os encontrados por outros autores. BLOCK e col. (4) verificaram que ratos alimentados com rações deficientes em iodo $(0,7-2,3 \mu g$ de iodo/loog de raçäol, associadas a produtos derivados de soja co mo farinha crua ou desengordurada e tostada, isolado protéico e fórmulas infantis (leite de soja), provocavan um aumento no peso da glàndula, jā na la. ou 2a. semana. Segundo os autores essa 
TABELA 7 - Acão das frações de alto peso molecular sobre o crescimento e peso de örgãos. Raçóes com restriçäo en iodol, 1 .

\begin{tabular}{|c|c|c|c|c|c|c|c|c|c|}
\hline \multirow{2}{*}{ Grupos } & & \multirow{2}{*}{ Dias } & \multicolumn{2}{|c|}{ Peso rato $(g)$} & \multirow{2}{*}{$\begin{array}{l}\text { Ração } \\
\text { ingerida } \\
(g)\end{array}$} & \multicolumn{4}{|c|}{ Peso/100g rato } \\
\hline & & & Inicial & Fina 1 & & $\begin{array}{c}\text { Tireōide } \\
\text { mg }\end{array}$ & $\begin{array}{c}\text { Figado } \\
\text { g }\end{array}$ & $\begin{array}{c}\text { Baco } \\
9\end{array}$ & $\underset{g}{\mathrm{Rim}}$ \\
\hline Glüten & & 10 & $\begin{array}{r}100,3 \\
+\quad 7,9\end{array}$ & $\begin{array}{r}167,7 \\
+\quad 11,9 \\
\mathrm{a}\end{array}$ & $\begin{array}{r}182,8 \\
\pm \quad 12,1\end{array}$ & $\begin{array}{r}8,58 \\
+\quad 1,77^{a}\end{array}$ & $N D$ & ND & ND \\
\hline FOA & & 10 & $\begin{array}{r}100,0 \\
\pm \quad 6,5\end{array}$ & $\begin{array}{r}169,2 \\
+\quad 16,7 \mathrm{ac}\end{array}$ & $\begin{array}{r}179,4 \\
+\quad 72,6\end{array}$ & $\pm \begin{array}{r}32,72 \\
\pm\end{array} 2,45 \mathrm{bc}$ & ND & ND & ND \\
\hline ResTduo & Extr. $\vec{A} g u a$ & 10 & $\begin{array}{r}96,5 \\
\pm \quad 5,5\end{array}$ & $\begin{array}{r}160,5 \\
\pm \quad 10,8 \mathrm{ac}\end{array}$ & $\pm \quad 174,0$ ac & $\pm \begin{array}{r}12,03 \\
2,77\end{array}$ & ND & ND & ND \\
\hline Glüten & & 14 & $\begin{array}{r}75,2 \\
\pm \quad 6,6\end{array}$ & $\begin{array}{r}131,2 \\
\pm \quad 10,7\end{array}$ & $\begin{array}{r}182,6 \\
+\quad 14,4\end{array}$ & $\begin{array}{r}7,35 \\
\pm \quad 7,54\end{array}$ & $\begin{array}{r}4,84 \\
\pm 0,33^{\mathrm{a}}\end{array}$ & $\begin{array}{r}0,32 \\
+0,04\end{array}$ & $\pm_{-0,06}^{0,76}$ \\
\hline FDA & & 14 & $\begin{array}{r}76,6 \\
+\quad 5,8\end{array}$ & $\begin{array}{r}136,0 \\
\pm \quad 10,4\end{array}$ & $\begin{array}{r}185,0 \\
\pm \quad 10,7 \mathrm{ac}\end{array}$ & $\begin{array}{l}77,63 \mathrm{bc} \\
7,84 \mathrm{~b}\end{array}$ & $\begin{array}{r}4,31 b c \\
-0,25\end{array}$ & $\pm 0,30 \mathrm{ac}$ & $\pm 0,81 \mathrm{bc}$ \\
\hline $\begin{array}{l}\text { Residuo } \\
\text { Acetona }\end{array}$ & Metanot- & 19 & $\begin{array}{r}76,6 \\
\pm \quad 6,7\end{array}$ & $\begin{array}{r}137,7 \\
\pm \quad 9,8\end{array}$ & $\begin{array}{r}185,0 \\
+\quad 14.9\end{array}$ & $\begin{array}{r}77,20 \mathrm{bc} \\
+\quad 2,77\end{array}$ & $\begin{array}{r}4,06 \\
-0,42 \mathrm{bc}\end{array}$ & $\stackrel{0,32}{ \pm}-0,04 \mathrm{ac}$ & $\begin{aligned} & 0,79 \\
+ & 0,04\end{aligned}$ \\
\hline Glüten & & 84 & $\begin{array}{r}48,1 \\
\pm \quad 2,0\end{array}$ & $\begin{array}{r}299,7 \\
\pm \quad 17,9\end{array}$ & $\begin{array}{r}7220,4 \\
\pm \quad 130,0^{\circ}\end{array}$ & $\begin{array}{r}\quad 3,65 a \\
\pm \quad 1,41^{a}\end{array}$ & $\begin{array}{r}3,38 \\
+0,12\end{array}$ & $\begin{array}{l}0,21 \\
+0,05 a\end{array}$ & $\begin{array}{r}0,64 \\
-0,04\end{array}$ \\
\hline Res $\hat{i} d u o$ & Ext. Agua & 84 & $\begin{array}{r}48,3 \\
\pm \quad 2,3\end{array}$ & $\begin{array}{r}291,1 \\
\pm 31,9^{a}\end{array}$ & $\begin{array}{r}1302,2 \\
\pm \quad 741,49\end{array}$ & $\begin{array}{r}74,45 \\
3,73^{b}\end{array}$ & $\begin{array}{l}3,41 \\
+0,39\end{array}$ & $+0,19 \mathrm{a}$ & $\stackrel{0,67}{ \pm 0,06^{a}}$ \\
\hline
\end{tabular}

TMèdia e Desvio Padräo

${ }^{2}$ Letras iguais indicam que não houve diferença significativa $(P>0,05)$ 
ação poderia ser revertida apōs a introdução de $160 \mathrm{Hg}$ de iodol $1100 \mathrm{~g}$ de ração.

outros pesquisadores $(58)$ encontraram que ratos alimenta das com rações preparadas com derivados de soja (queijo de soja) e deficientes em iodo, mostraram um aumento no peso da giándula, $\underline{e}$ feito que podia, em parte, ser revertido pela introdução de iodo. KIMURA e col. (25) observaram um aumento da tireóide um pouco menor em ratos alimentados com proteína isolada de soja do que quando alimentados com farinha desengordurada de soja, porém, em ambos os casos, observaram um aumento bastante significativo quando comparados com seu grupo controle, que tambëm recebia ração pobre em iodo.

Quanto ao peso relativo dos outros órgãos, determinado em ensaios de 14 e 84 dias, foi encontrada uma diminuição significativa no peso do fígado, nos ensaios de 74 dias, sendo de $10,9 \%$ pa ra o grupo FDA e $15,5 \%$ para o grupo Resíduo Metanol-Acetona (Tabe 1 a 7). Nesse mesmo experimento observanios, tambēm, um aumento sig nificativo de $6,6 \%$ do peso do rim sō no grupo que recebeu FDA (Tá bela 7).

Com relação do efeito especĩfico sobre a tireóide, nos estudos de 10 dias não verificamos alteraçöes significativas na \% de captação relativa tanto do grupo FDA ben como no grupo que recebeu Resĩduo Extração com Agua (Tabela 8). Porēm nos ensaios de 14 dias observamos uma diminuição em relação ao grupo controle de $34,8 \%$ e $31,5 \%$, respectivamente para o grupo FDA e Residuo MetanolAcetona (Tabela 8).

Essa diminuição foi tambëm demonstrada no Resíduc da Ex tração com Agua nos ensaios de 84 dias, correspondendo a $54,1 \%$ em 
TABELA 8 - Ação das frações de alto peso molecular sobre a tireóide. Raçōes com restrição em iodo ${ }^{7}, 2$.

\begin{tabular}{|c|c|c|c|c|c|c|c|c|}
\hline Grupos & Dias & $\begin{array}{l}\text { \% Captação } \\
\text { relativa }\end{array}$ & $\%$ MIT & $\%$ DIT & $\% T_{3}$ & $\% \mathrm{~T}_{4}$ & MIT/DIT & $\mathrm{T}_{3} / \mathrm{T}_{4}$ \\
\hline Glüten & 10 & $\begin{array}{l}14,08 \\
\pm 3,79\end{array}$ & $\begin{array}{r}17,86 \\
\pm \quad 2,02\end{array}$ & $\begin{array}{r}37,43 \\
\pm 2,35\end{array}$ & $\begin{array}{l}1,92 \\
\pm 0,60\end{array}$ & $\begin{array}{r}14,84 \\
\pm \quad 2,84\end{array}$ & $\begin{array}{r}0,47 \\
\pm 0,07\end{array}$ & $\begin{array}{r}0,12 \\
\pm 0,02\end{array}$ \\
\hline FOA & 10 & $\pm \begin{array}{r}3,93 \\
4,68 \mathrm{ac}\end{array}$ & $\begin{array}{r}23,39 \\
\pm \quad 1,40\end{array}$ & $\begin{array}{r}27,53 \mathrm{~b} \\
\pm \quad 1,70\end{array}$ & $\begin{array}{l}2,95 b \\
-0,42\end{array}$ & $\begin{array}{r}19,04 \mathrm{~b} \\
\pm \quad 2,55\end{array}$ & $\begin{aligned} & 0,85 \\
\pm & 0,07\end{aligned}$ & $\begin{array}{r}0,75 \mathrm{~b} \\
\pm 0,03\end{array}$ \\
\hline Res iduo Ext. Agua & 10 & $\begin{array}{r}14,88 \\
\pm \quad 6,30 \mathrm{ac}\end{array}$ & No & NO & ND & NO & ND & ND \\
\hline Giüten Ext. Aguá & 14 & $\pm 22,66 \mathrm{a}$ & $\begin{array}{r}22,32 \\
+\quad 2,97\end{array}$ & $\begin{array}{r}35,60 \\
\pm \quad 4,62\end{array}$ & $\begin{array}{l}7,57 \\
-0,17\end{array}$ & $\pm \begin{array}{l}13,58 \\
\pm \\
1,55^{a}\end{array}$ & $\pm_{-0,11}^{0,63}$ & $+0,11 \mathrm{a}$ \\
\hline FQA & 14 & $\begin{array}{l}14,76 \mathrm{bc} \\
\pm \\
2,55\end{array}$ & $\pm^{28,98}, 69 \mathrm{bc}$ & $\frac{1}{2}^{30,02^{b c}} 1,34$ & $\begin{array}{l}2,28 \mathrm{bc} \\
+0,58\end{array}$ & $\begin{array}{r}11,76 \\
\pm \\
-3,64\end{array}$ & $\begin{array}{r}0,96 \mathrm{bc} \\
+0,08\end{array}$ & $\begin{array}{rl} & 0,20 \mathrm{bc} \\
-0,06 & \mathrm{bc}\end{array}$ \\
\hline $\begin{array}{l}\text { Residuo Metanol- } \\
\text {-Acetona }\end{array}$ & 34 & $\begin{array}{r}15,52 \mathrm{bc} \\
\pm \quad 4,82\end{array}$ & $\begin{array}{r}30,52 \mathrm{bc} \\
\pm \quad 2,70\end{array}$ & $\begin{array}{r}29,89 \mathrm{bc} \\
\pm \quad 1,90\end{array}$ & $\begin{aligned} & 3,32 \mathrm{bd} \\
\pm & 0,97\end{aligned}$ & $\pm \begin{array}{r}34,51 \\
-3,35 \mathrm{ac}\end{array}$ & $\pm 0,02 \mathrm{bc}$ & $\pm 0,23 \mathrm{bc}$ \\
\hline Giüten & 84 & $\pm \begin{array}{l}12,31 \\
1,37\end{array}$ & $\begin{array}{r}28,14 \\
3,36^{a}\end{array}$ & $\begin{array}{r}29,96 \\
\pm \quad 4,07^{a}\end{array}$ & $\pm_{-0,93}^{2,74} \mathrm{a}$ & $\begin{array}{r}20,36 \\
+\quad 2,91\end{array}$ & $\begin{array}{r}0,96 \\
\pm 0,18^{a}\end{array}$ & $+_{-0,03}^{0,13}$ \\
\hline Residuo Ext. Agua & 84 & $\begin{array}{r}6,66 \mathrm{~b} \\
+\quad 2,89\end{array}$ & $\begin{array}{r}34,42 b \\
+\quad 4,09\end{array}$ & $t_{-3,40}^{25,70}$ & $\begin{array}{l}5,03 \mathrm{~b} \\
-1,58\end{array}$ & $\begin{array}{r}13,07 \\
\pm 3,95\end{array}$ & $\begin{array}{r}7,35 b \\
\pm 0,23\end{array}$ & $\pm 0,42 \mathrm{~b}$ \\
\hline
\end{tabular}

TMedia e Desvio Padräo

${ }^{2}$ Letras iguais indicam que näo houve diferenca significativa $(P>0,05)$ 
relação ao seu Controle (Tabelā 8).

Com relação aos dados referentes à $\%$ de hormönios marca dos, a nível tireoidiano, constatamos alteraçöes semelhantes en praticamente todos os grupos analisados (Tabeia 8).

Assim, observamos um aumento da \% MIT $e \% T_{3}$ acompanhado de uma diminuição da \% DIT. Verificamos, tambēm, uma diminuição da \% $T_{4}$ nos ensaios de 10 e 84 dias que não foi porēm observada nos en saios de 14 dias. Por outro lado as relações MIT/DIT e $T_{3} / T_{4}$ apre sentaram-se aumentadas em relação aos seus controles em todas os casos analisados.

A dosagem dos hormônios séricos só foi realizada no ensaio de 84 dias. Os resultados de $T_{3}$ sérico do grupo controle foi de $1,00 \pm 0,11 \mathrm{ng} / \mathrm{ml}$ e do grupo que recebeu Resĩduo da Extração com Agua foi 1,i4 $\pm 0,6 \mathrm{ng} / \mathrm{ml}$; apōs anălise estatistica verifica mos que essa diferença não foi significativa. O $T_{4}$ sérico, porém, mostrou diferença significativa entre o grupo controle $\quad(5,07 \pm$ $0,75 \mathrm{\mu g} / 100 \mathrm{ml})$ e o experimental $(2,81 \pm 0,90 \mathrm{\mu g} / 100 \mathrm{ml})$.

Os nossos resultados vão confirmar, em parte, os resultados obtidos por alguns pesquisadores $(58)$ os quais verificaram que ratos alimentados com derivados de soja mostraram uma diminuição na \% de captação de I-131 pela tireóide e um aumento na relação MIT/DIT.

E oportuno enfatizar aqui que os resultados obtidos com a FDA ou com os resĩduos obtidos, quer por exiração com ägua quer por extração com metanol e acetona, não mostraram diferenças acen tuadas; a unnica exeção foi relativa às \% $T_{3}$ na tireóide (vide Tabela 8).

Isso nos leva a crer que o fator, com maior ação na ti- 
reōide, não foi extraído durante as etapas de fracionamento da soja e dessa forma podemos dizer que ele não é solúvel em meio aquoso ( $\mathrm{pH} 4,2)$, metanol $90 \%$ e acetona. O tratamento com metanol $(67)$ foi realizado com a finalidade de extrair principalmente as saponinas, uma vez que como jā foi sugeridoque elas poderiam ser um dos compostos responsāveis pela indução do bócio provocado pela soja(57). Apös extração com metanol, o resíduo resultante foi ex traîdo com acetona para remoção das flavonóides presentes os quais tambēm poderiam ter alguma ação na tireóide, como sugerido por ou tros pesquisadores que verificaram que muitos flavonóides são capazes de acelerar( ${ }^{(36)}$ ou diminuir(23) o metabolismo basal e, depr $\underline{i}$ mir (52) ou aumentar (48) a captação de radioiodo pela tireōide. Por outro lado FILISETTI e LAJOLO (12) verificaram que as isoflavonas da soja eram incapazes de provocàr alterações nas tireóides, pelo menos em ensaios de $24 \mathrm{hs}$.

Para uma melhor interpretação dos resultados obtidos rea lizamos um exame anatomopatológico da tireóide a fim de verificar as alterações provocadas a nível celular e ter indicações adicionais que permitissem sugerir algum mecanismo de ação.

4.3 - Exame Anatomopatológico da Tireóide

Esse exame só foi realizado nos dois ensaios de 84 dias pois, sō apōs um período relativamente longo $\vec{e}$ que poderiamos perceber com mais nitidez as alteraçōes provocadas pelos produtos de fracionamento da soja nas estruturas do folìculo. Nesse caso os produtos testados foram: Resĩduo da Extração com Ägua e Extrato Aquoso. 


\section{3 .1 - Exame macroscōpico}

A observação macroscōpica da tireōide mostrou um aumento de volume só no grupo de animais que receberam Residuo de Extração com Agua e, nesse caso, apresentavam uma congestão visivel mente maior em relação a seu Controle.

\subsection{2 - Exame microscōpico}

Apenas o grupo que recebeu Residuo de Extração com Agua revelou alterações dignas de nota.

Os cortes histológicos, corados com HE e PAS, dos anima is do grupo Controle foram representados na Figura 3 e 4 . Na figura 3 (HE) observanos que os foliculos apresentam um epitēlio uniestratificado com quantidade variāvel de colóide e com predominān cia do mesmo na região sub-capsular. Os nūcelos apresentam uma cromatina ora frouxa ora condensada (hipercromātica) com nuclēo los visiveis apenas na frouxa. 0 interstício estä representado por un delicado estroma conjuntivo-vascular com discreto grau de congestão.

Na Figura 4 (PAS) observamos que não há depleção de colóide, mas os folículos da perĩferia o contēm em maior quantidade, em relação aos da região central.

OS cortes corados con HE e PAS correspondentes aos anima is do grupo experimental estão representados na Figura 5 e 6 . Na Fi gura 5 (HE) verificamos que os folículos são de tamanho ma is ou me nos uniforme e revestidos por um epitélio cilindrico uniestratificado. Os núcleos apresentam uma cromatina frouxa localizada mais 


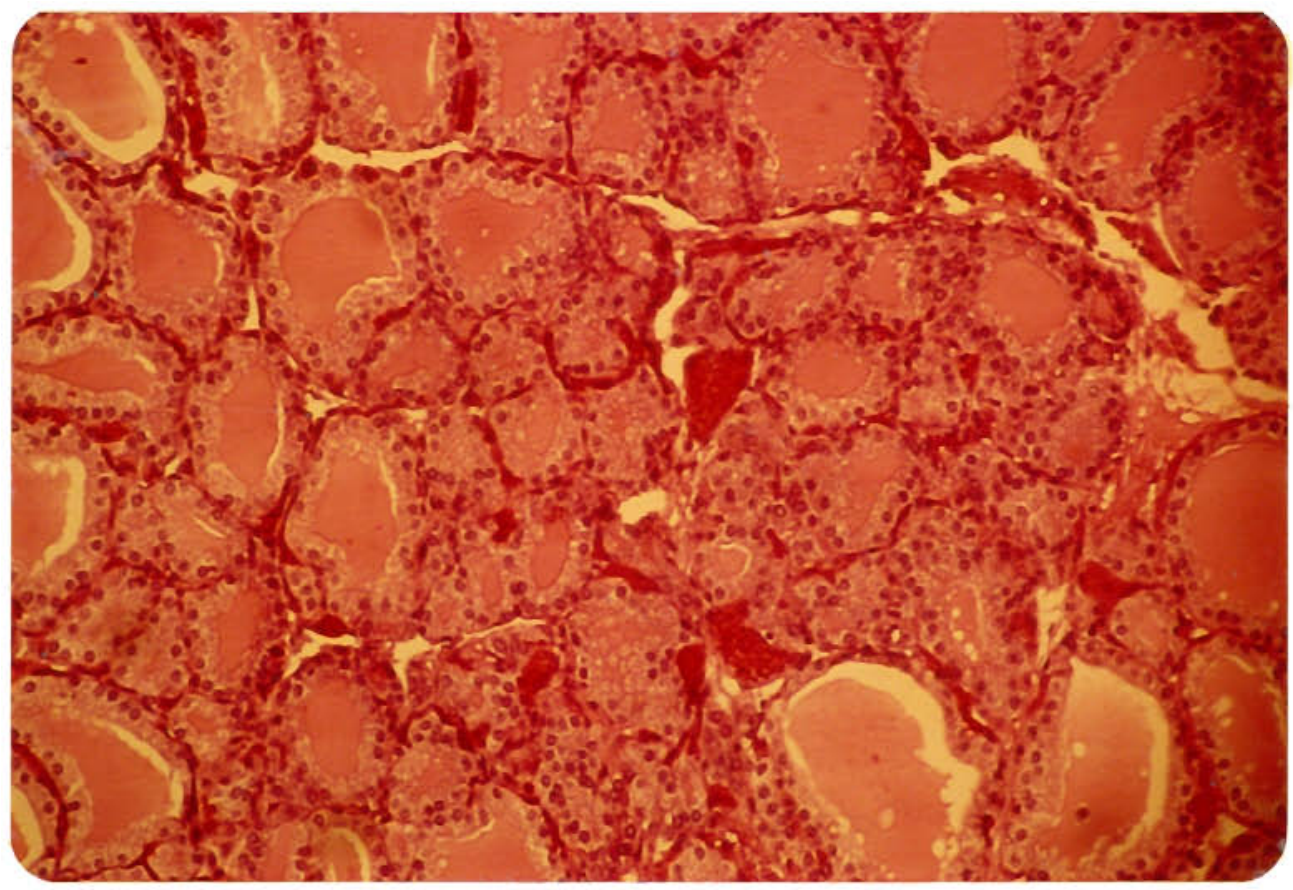

Figura 3 - Fotomicrografia de tireōide de rato do grupo con trole (Glūten). Aumento 100x. Coloração: H.E.

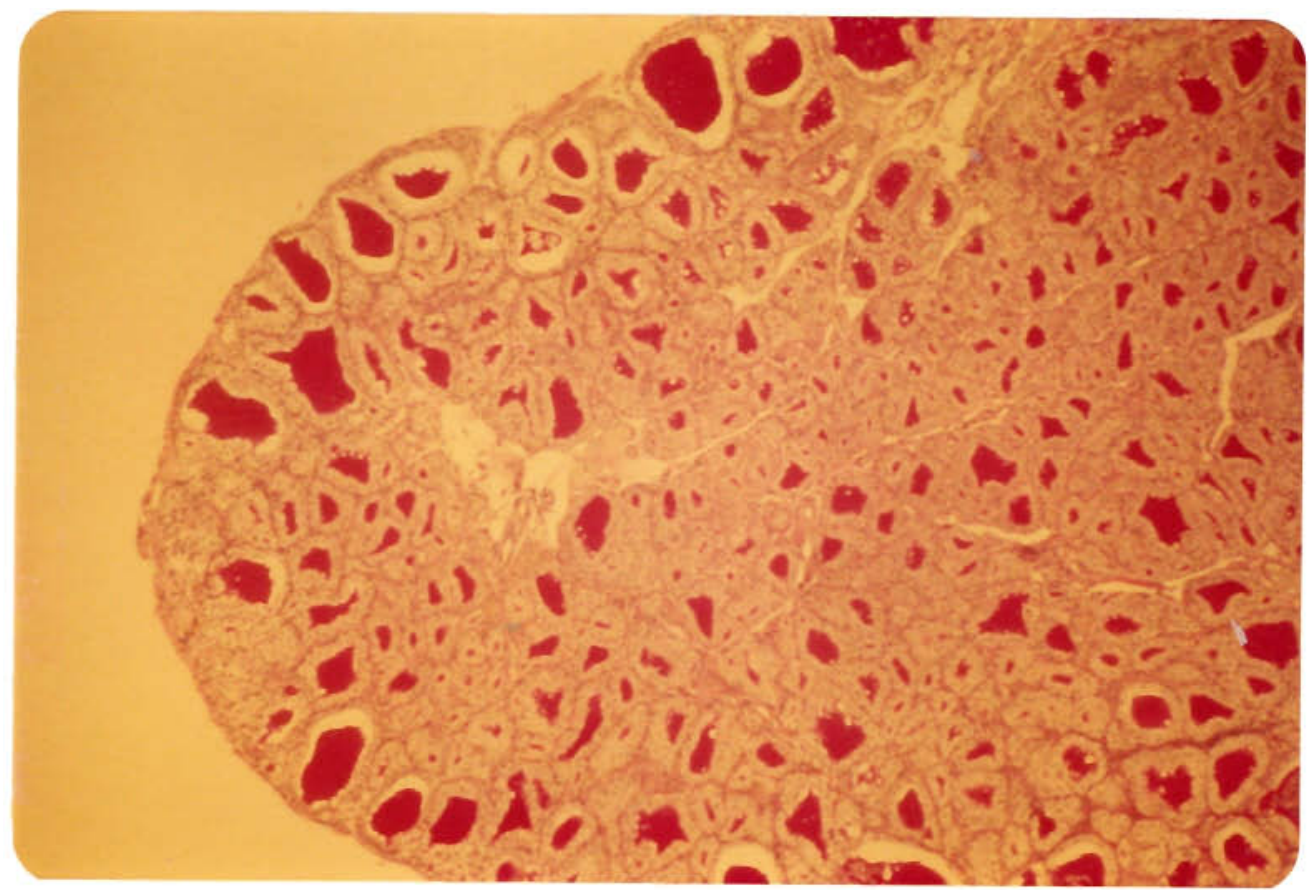

Figura 4 - Fotomicrografia de Tireōide de rato do grupo con trole (Glüten). Aumento 40x. Coloração: PAS 


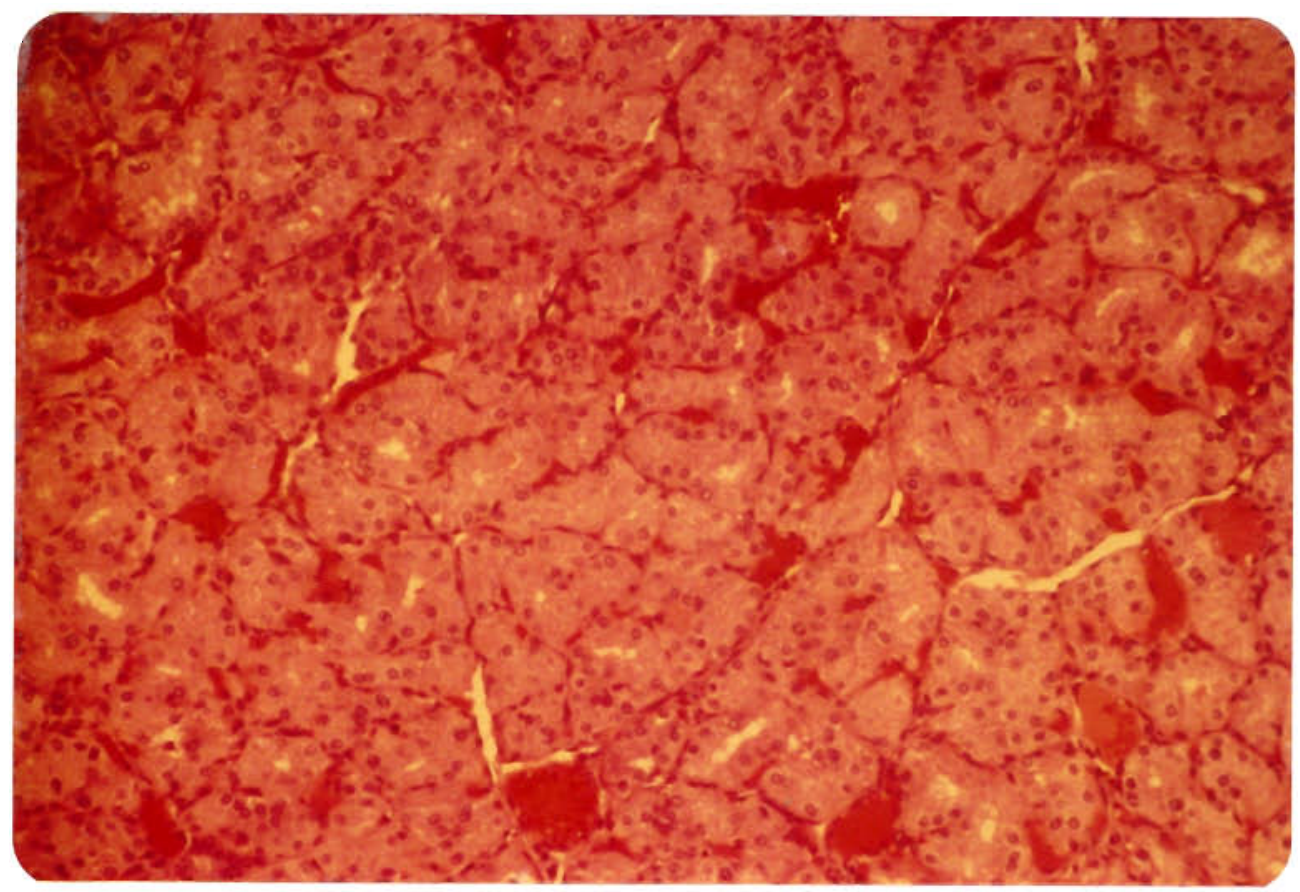

Figura 5 - Fotomicrografia de tireóide de rato do Grupo Residuo Extração com Agua. Aumento 100x. Coloração: H.E.

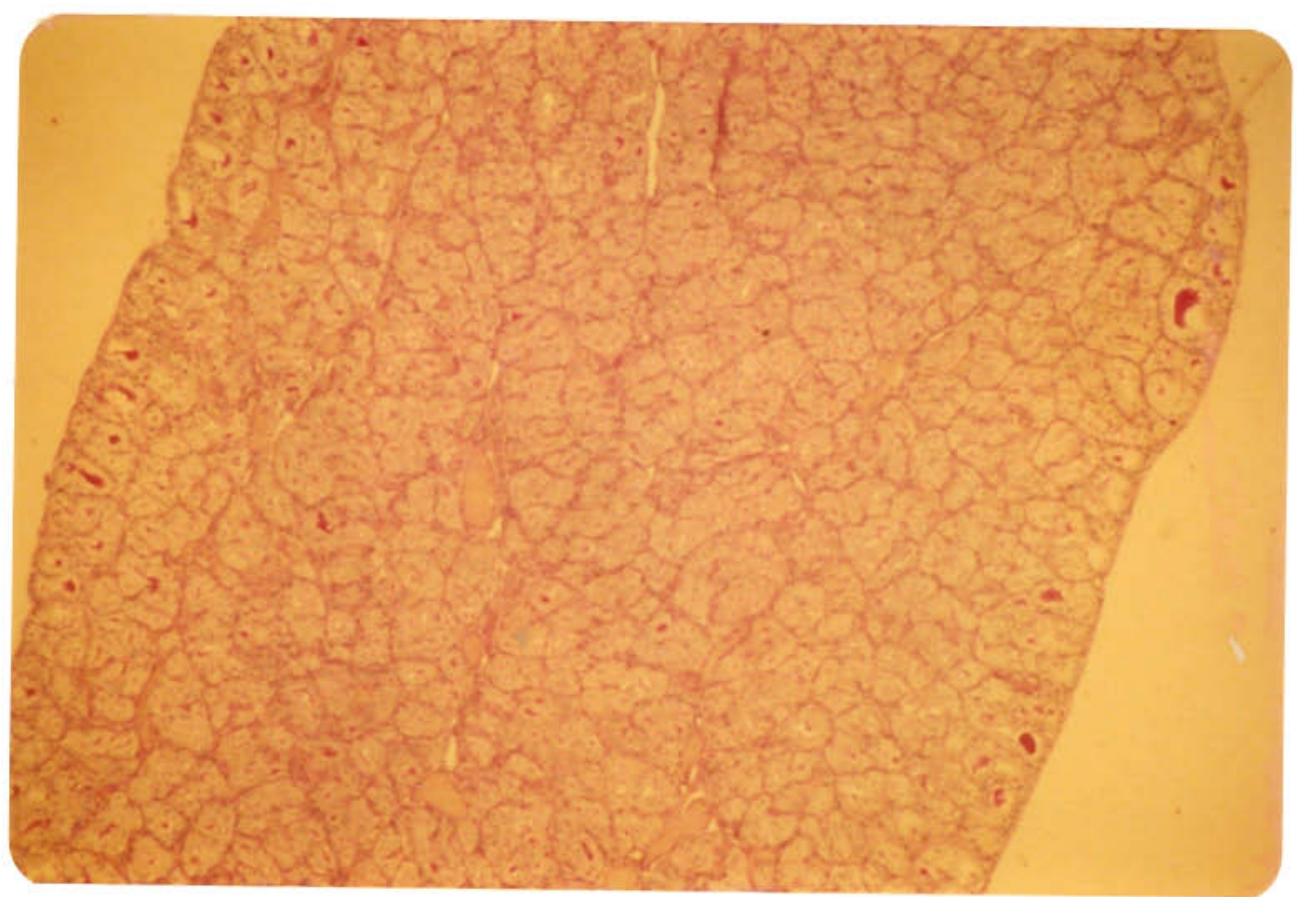

Figura 6 - Fotomicrografia de tireōide de rato do Grupo Resìduo Extração com Água. Aumento 40x. Colora ção: PAS. 
na região periférica, deixando no centro um halo claro onde visualizamos nitidamente o nuclēolo. O interstício está representado por um delicado estroma conjuntivo-vascular; o que chama atenção é a congestão homogẽnea e intensa. Na Figura 6 (PAS) observamos que na porção central da giandula a depleção do colóide é intensa, sendo que os foliculos um pouco mais ricos em colóide estão na re giầo sub-capsular.

Este tipo de imagem histológica (Resĩduo e Extração com Agua) está representada em $75 \%$ dos casos analisados. Em dois casos desse grupo, isto $\bar{e}, 25 \%$, a imagem histolögica estava mais prö xima da imagem descrita para o grupo Controle e, portanto, não foi possîvel fazer um diagnóstico diferencial do corte histológico desses animais em relação ao grupo Controle. Nesse caso, porém, ambas as \% de captação relativa foram as mais altas desse grupo, porēm, inferiores à mêdia do grupo controle; isso talvez explique a variação da imagem histolögica dentro do grupo.

Informações semelhantes foram encontradas por outros pes quisadores $(58)$ os quais, por outro lado, observaram que ratos âli mentados durante 2 meses, com rações que continham derivados de so ja e suplementados com iodo (20 $\mu \mathrm{g} / 100 \mathrm{~g}$ ração), não mostravam aumento na glāndula e, o tamanho e a distribuição dos folículos pare cia norma ; contudo eles observaram um aumento de elementos para-foriculares.

Einteressante notar que o comportamento da tireōide, descrito até agora, é semelhante ao de uma giāndula que esteja com depleção em iodo $(8)(56)$, sō que ao invēs de termos um aumento na cap tação de $[-13]$ como seria o caso, observamos o inverso.

Apōs anālise detalhada do presente quadro chegamosà con 
clusão que o fator presente na soja, tanto o de ação fraca, presen te nas fraçōes de baixo peso molecular, como o mais ativo, pre sente nas fraçōes de alto peso molecular, agena nível de entrada de iodo.

As frações de baixo peso molecular, em ensaios realizados "in vitro" e em experimentos de 18 dias (dietas com iodo) e 10 dias (dietas com deficiēncia em jodo), provocaram uma diminuição na \% de captação relativa; esse mesmo efeito foi observado em en saios de 14 e 84 dias com frações de alto peso molecular. Pelo ex posto acima descartamos a hipótese do fator agir no mecanismo de organificação do iodo, ou no mecanismo oxidativo de acoplamento de pares de DIT, para dar origem ao $T_{4}$ ou de pares de MIT e DIT para dar origem ao $T_{3}(59)$.

A ação resulta no aumento da sīntese de MIT e $T_{3}$ e, numa diminuição de DIT e $T_{4}$, como consequência, hā uma dininuição de $T_{4}$ sérico, o que por sua vez, através de um mecanismo de retroalimentação via hipōfise, induziria a liberação de TSH estị mulando consequentemente as células do lóbulo a aumentarem a velocidade de sỉntese da tireoglobulina. Isso, ao mesmo tempo, provocaria um aumento dr pinoxitose e como resultado final, have / $c$, ria uma rarefação do colóide no interior dos ácinos, como observado.

\section{4 - Efeito dos Produtos da Hidrölise Enzimātica}

Durante as etapas de processamento, para obtenção do Re sĩduo Metanol-Acetona, forani eliminados uma série de compostos de baixo peso molecular que poderiam ser os responsāveis pela ação na tireóide; contudo como iá descrito anteriorinente, essa fração 
continuou ativa. Apōs anālise desse produto, verificamos que era constituido principalmente de proteina e fibra; isso nos levou a pensar que uma hidrólise enzimática, com pepsina e pancreatina, poderia destruir a atividade do fator, caso estivesse ligado a compostos de origem protéica. Por outro lado, a hidrólise poderia "liberar" algum composto ativo que estivesse ligado à prote nal 27$)$ e, nesse caso, poderiamos separa-1o, numa la. fase, da fibra existente.

Apōs a hidrölise verificamos, porēm, que tanto o hidrolisado como o resíduo manifestavarn ação na tireóide e, que essa ação era semelhante (Tabela 9 e 10).

observou-se em ambas as frações uma diminuição significativa na $\%$ de captação relativa e um aumento do peso relativo da tireöide. A \% DIT mostrou uma diminuif̧ão significativa em ambos os grupos experimentais, em relação ao Controle, não havendo, porēn, diferença entre eles. Por outro lado, a \% T mostrou uma diminuição em relaçāo ao Controle apenas para Resĩduo da Hidrōi ise. Apesar do aumento da \% MI em ambos os caos não ser significativa, observamos um aumento de $\mathrm{T}_{3}$ causado pelo Hidrolisado.

Normalmente é mais fácil analisar esse tipo de dados atravês das relações entre os hormōnios e os respectivos precurso res; verificou-se assim, em ambos os casos, um aumento das relações MIT/OIT e $T_{3} / T_{4}$, não havendo porém diferença significativa dos dois grupos experimentais entre si.

Devemos salientar ainda que o Coeficiente de Eficäcia Alimentar do Hidrolisado $(0,34 \pm 0,03)$ e do Residuo da Hidrólise $\{0,33 \pm 0,02)$ tambēm não apresentaram variação significativa entre si ou em relação ao seu controle $(0,33 \pm 0,02)$. 
TABELA 9 - Efeito dos produtos da hidrōlise enzimätica sobre o crescimento e peso da tireōi de. Raçōes com restrição en iodal,2.

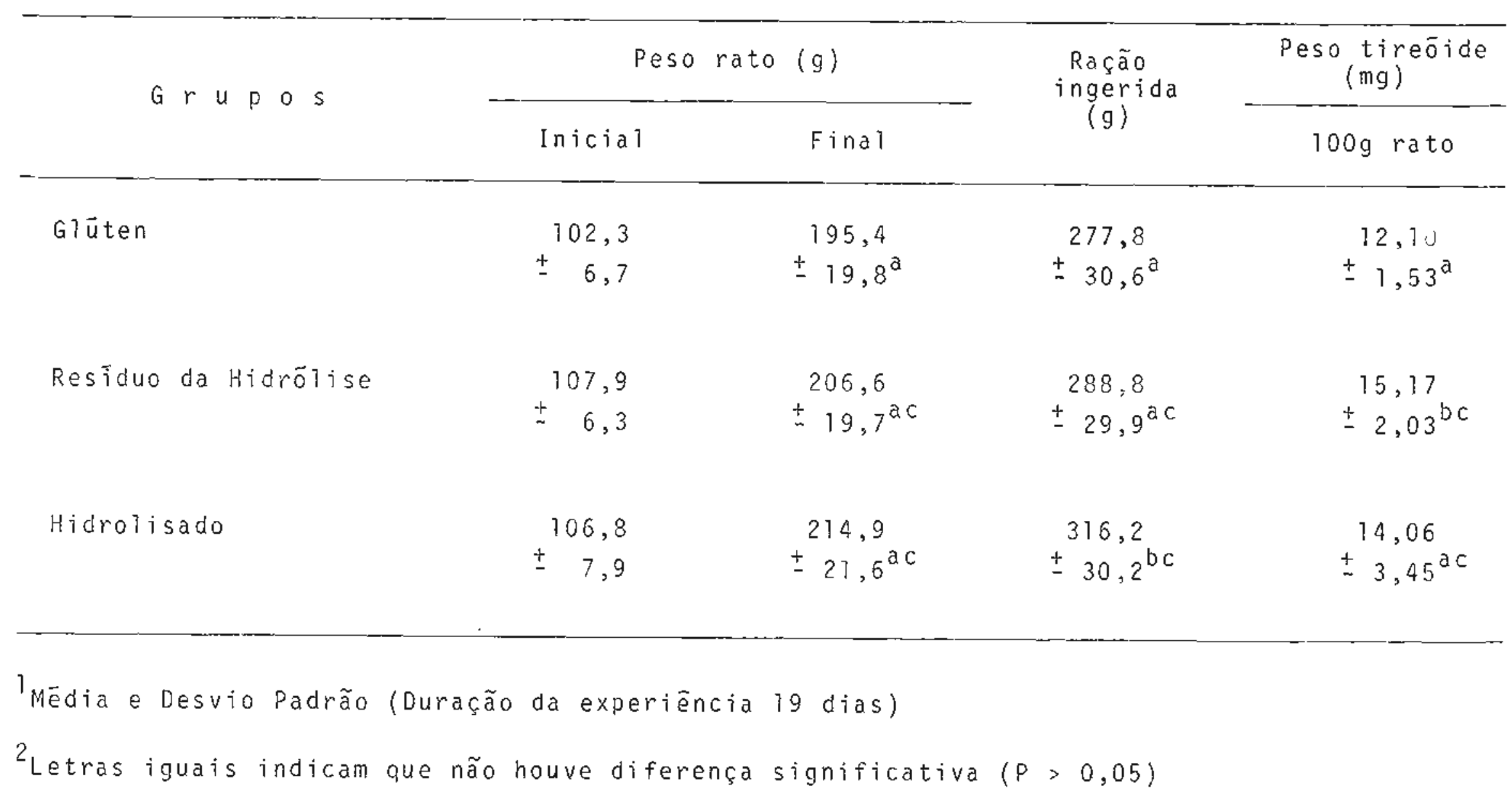


TABELA 10 - Efeito dos produtos da hidrōijse enzimātica sobre a tireóide. Rações com restrição de iodol, 1,2

\begin{tabular}{|c|c|c|c|c|c|c|c|c|}
\hline Grupos & Dias & $\begin{array}{l}\text { \% Captação } \\
\text { relativa }\end{array}$ & $\%$ MIT & $\&$ DIT & $\% \mathrm{~T}_{3}$ & $\% \mathrm{~T}_{4}$ & $\mathrm{MIT} / \mathrm{DIT}$ & $\mathrm{T}_{3} / \mathrm{T}_{4}$ \\
\hline Gluten & 19 & $\begin{array}{r}19,69 \\
\pm \quad 3,41^{\mathrm{a}}\end{array}$ & $\begin{array}{r}26,42 \\
\pm \quad 1,68^{a}\end{array}$ & $\begin{array}{r}32,27 \\
+\quad 0,99^{a}\end{array}$ & $\begin{array}{c}1,84 \\
\pm 0,22^{3}\end{array}$ & $\begin{array}{c}9,3] \\
\pm 2,07^{\mathrm{a}}\end{array}$ & $\begin{aligned} & 0,81 \\
+ & 0,04^{\mathrm{a}}\end{aligned}$ & 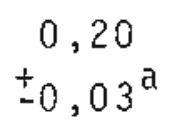 \\
\hline Res îduo da hidrölise & 19 & $\begin{aligned} & 11,55 \\
\pm & 3,86\end{aligned}$ & $\begin{array}{r}27,42 \\
\pm \quad 2,52\end{array}$ & $\begin{array}{r}27,60 \\
+\quad 3,44 b c\end{array}$ & $\begin{array}{c}2,23 \\
\pm 0,71 \mathrm{ac}\end{array}$ & $\begin{array}{c}6,26 \\
+2,08\end{array}$ & $\begin{aligned} & 1,01 \\
\pm & 0,20\end{aligned}$ & $\begin{aligned} & 0,37 \\
+ & 0,10\end{aligned}$ \\
\hline Hidrolisado & 19 & $\begin{aligned} & 8,90 \\
\pm & 2,78^{b c}\end{aligned}$ & $\begin{array}{r}29,16 \\
\pm \quad 5,75^{a c}\end{array}$ & $\begin{array}{r}25,84 \\
+\quad 2,99\end{array}$ & $\begin{array}{r}3,71 \\
\pm 1,25\end{array}$ & $\begin{array}{l}9,86 \\
+3,32^{\mathrm{ad}}\end{array}$ & $\begin{aligned} & 1,14 \\
+ & 0,27\end{aligned}$ & $\begin{aligned} & 0,41 \\
\pm & 0,22\end{aligned}$ \\
\hline
\end{tabular}

Média e Desvio Padrão

${ }^{2}$ Letras iguais indicani que não houve diferença significativa $(P>0,05)$ 
Em vista desses resultados podemos afirmar, somente, que a hidrōlise enzimätica não inativa o fator com ação na tireōide e, que o produto responsável por essa ação encontra-se distribuído em ambas as frações, igualmente.

Avaliando-se os dados obtidos por nōs, associados aos da Titeratura podemos concluir que:

a) a soja autoclavada apresenta um fator de baixo peso molecular, termoresistente, extraível por àgua e solúvel em aceto na, capaz de reduzir a captação de iodo em ensaios agudos "in vivo" e em tireóides isoladas "in vitro";

b) esse fator, de baixo peso molecular, tem pequeno significado biolōgico, por não ser ativo, quando administrado em raf̧ões por prazos longos, tanto em condições de restrição de iodo como em situaçōes de iodo normal;

c) existe um fator na soja autoclavada, associado à fração de alto peso molecular, não hidrolisāvel pela pepsina e pancreatina, capaz de, quando presente em raçōes com baixos teores de iodo, provocar, a partir de 1.4 dias, um aumento no peso da tireóide, uma redução na captaçăo de iodo e alte rações a nível glandular dos hormōnios e seus precursores. Em prazos mais longos ( 84 dias) esse fator é capaz de provo car ainda a diminuição do $T_{4}$ sérico,associada a mudanças na histologia da glāndula, representadas, principalmente, por redução no colóide;

d) o seu mecanismo tem semelhança com fatores que agem a nível de captação de iodo. 
5 - REFERENCIAS BIBLIOGRÁFICAS*

1 - ASP, Nils-G.; JOHANSSON, Claes-G.; HALLMER, H.; SILJESTRÖM, M. Rapid enzymatic assay of insoluble and soluble dietary fiber. J.Agric. Food Chem., Washington, 311:476-82, 1983.

2 - ASSOCIATION OF OFFICIAL ANALYTICAL CHEMISTS. Official methods of analysis of the $A O A C$. 33. ed. Washington, AssoC. Off. Agric. Chem. 1980. p.858.

3 - BECK, R.N. Soy flour and fecal thyroxine loss in rats. Endocrinology, Springfield, 62:587-92, 1958.

4 - BLOCK, R.J. \& MANDL, R.H. The curative action of iodine on soybean goiter and the changes in the distribution of iodoamino acids in the serum and in thyroid gland digests. Arch. Biochem., New York, 93:15-24, 1961.

5 - cevallos, J.L.G. Factores etiologicos del bocio endemico. Invest. Clin., Maracaibo, $21: 138-49,1980$.

6 - Delange, F.M. \& ERMANS, A.M. Endemic goiter and cretinism: naturally occurring goitrogens. Pharmacol. Ther, Part $\mathrm{C}$, oxford, 1:57-93, 1976.

7 - EKINS, R.P. The estimation of thyroxine in human plasma by electrophoretic technique. clin. Chim. Acta, Amsterdam, 5: $453-9,1960$.

*De acordo com as normas preconizadas jela ASSOCIAÇAO BRASILEIRA DE NORMAS TECNICAS (ABNT). As abreviaturas dos periödicos seguem o CHEMICAL ABSTRACTS SERVICE SOURCE INDEX, Columbus, 1980. 
8 - ERMANS, A.M. Endemic goiter and endemic cretinism. In: DeGROOT, L.J.,ed. et alii. Endocrinology. New York, Grune \& Stratton, 1979. v.1, p. 501-8.

9 - FARRIS, E.J. The rat in laboratory investigation. 2.ed. New York, Hafner Publishing Company, 1963. p.76-7.

10 - FEdere, W.T. Experimental design. New York, MacMilian, 3955. $544 \mathrm{p}$.

11 - FENHICK, G.R.; HEANEY, R.K.; MULLIN, W.J. Glucosinolates and their breakdown products in food and food plants. CRC Crit. Rev. Food Sci. Nutr., Cleveland, 18:123-201, 1983.

12 - FILISETTI, T.M.C.C. \& LAJOLO, F.M. Thyroid active factor in heated soybean fractions. J. Food Sci., Chicago, 45:1179$82,1186,1980$.

13 - FILISETTI, T.M.C.C. \& LAJOLO, F.M. Efeito da ingestão de fra ções de soja crua ou autoclavada sobre a tireóide de ratos. Arch. Latinoam. Nutr., Caracas, 31:287-302, 1981.

14 - FilisetTi, T.M.C.C.; MARquEZ, U.M.L.; MANCINI FILho, J.; LAJOLO, F.M. Fatores antinutricionais em alguns produtos co merciais de soja. Rev. Firm. Bioquim. Univ. S. Paulo, 15: $93-108,1977$.

15 - FOX, M.R.S. \& BRIGGS, G.M. Salt mixture for purified-type diet. III. An improved salt mixture for chicks. J.Nutr., Philadelphia, 72:242-50, 1960.

16 - GREER, M.A. Nutrition and goiter. Physiol. Rev., Washington, 30: $: 513-48,1950$.

17 - GREER, M.A. Thyroid hormones. II. The naturat occurrence of goitrogenic agents. Recent Progr. Horm. Res., New York, 18:187-219, 1962 . 
18 - Halverson, A.W.; ZEPPLIN, M.; HART, E.B. Relation of iodine to the goitrogenic properties of soybeans. J. Nutr., Philadelphia, 38:115-29, 1949.

19 - HYDOVITZ, J.D. Occurence of goiter in an infant on soy diet. N. Engl. 3. Med., Boston, 262:351-3, 1960 .

20 - IINO, S. Comparison of the effects of various goitrogens on biosynthesis of thyroid hormones in vitro. Acta Endocrinol., Copenhagen, 36 :212-20, 196 ?.

21 - IKEDA, E.; NICOLAU, W.; MURAMOTO, E.; MARQUES DE ASSIS, L. ; PIERONI, R.R. Separaçäo de compostos iodados biliares e fecais por filtração em Sephadex G-25 M. Estudo do meta-

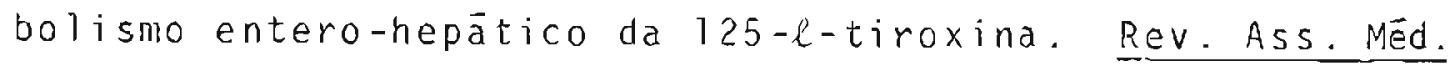
Brasil., São Paulo, 19:137-6, 1973.

22 - INTERNATIONAL DEVELOPMENT RESEARCH CENTER. Summary of the general discussion on chronic cassava toxicity. Ottawa, 1973. p. 159-62.

23 - JENEY, E. New date of pharmacology of flavonoids. Acta Physiol. Acad. Sci. Hung., Budapest, $34: 193-212,7968$.

24 - KIMURA, S. Comparative studies on the goitrogenic activities of defatted soybean and soybean protein isolate. Rep. Res. Soy Prot. Nutr., 1:48-50, 1980 .

25 - KIMURA, S.; KAWAMURA, M.; HiRAMA, M. Comparative studies on the goitrogenic activities of the soybean and soy protein isolate. Rep. Res. Soy Prot. Nutr., 3:18-23, 1982.

26 - KIMURA, S.; SUWA, J.; ITO, M.; SATO, H. Development of malignant goiter by defatted soybean with iodine-free diet in rats. Gann, Tokyo, 67:763-5, 1976. 
27 - KOHJI, H. Thiocyanate in soybean products. Kaseigaku Zasshi, Tokyo, 34 : $334-8,1983$.

28 - KONIUN, A.M.; EDELSTEIN, S.; GUGGENHEIN, K. Separation of a thyroid-active fraction from unheated soya bean flour. J. Sci. Food Agric., London, 23:549-55, 1972.

29 - KONIJN, A.M.; GERSHON, B.; GUGGEHEIN, K. Further purification and mode of action of a goitrogenic material from soybean flour. J. Nutr., Philadelphia, 103:378-83, 1973.

30 - LAJOLO, F.M. Estudo bromatolögico de concentrados protéicos de Sardinella aurita e de Tilapia melanopleura obtidospor extracãa com isopropanol. São paulo. Faculdade de Farmá cia e Bioquimica, 1969. [Tese de doutoramento\}.

31 - LIENER, I.E. Legume toxins in relation to protein digestibility: a review. J. Food Sci., Chicago, 41:1076-81, 1976.

32 - LIENER, I.E. Factors affecting the nutritional quality of soya products. J.Am. 0i\} Chem. Soc., Chicago, 58:406-15, 1981.

33 - LIENER, I.E. \& KAKADE, M.L. Protease inhibitors. In: LIENER, I. E. Toxic constituents of plant foodstuffs. New York, Academic Press, 1969. p.7-68.

34 - LISON, L. Histochemie et cytochemie aninales. 3. ed. Paris, Gauthier-vil1ars, 1960. 2v.

35 - MCCARRISON, R. The goitrogenic action of soya-bean and groundnut. Indian. J. Med. Res., New Delhi, 21:179-81, 1933.

36 - MCLAREN, G.A.; ASPLUND, R.0.; CROW, D.G.; TSAI, L. I.; PORTER FIELD, I.D. Influence of dried-grass silage and silage fractions on basal metabolic rate of rats. J. Nutr., Philadelphia, 83:218-24, 1964. 
37 - MEYER, E.W. Soya protein isolates for food. In: LAWRIE, R. A. Proteins as human food. London, Butterworths, 1970 . p. $346-62$.

38 - MICHALANY, J. Técnica histolögica em anatomia patolögica. São Paulo, E.P.U., 1980. P.46.

39 - MURPHY, B.P. The determination of thyroxine by competitive protein-binding analys is employing an anion-exchange resin and radiothyroxine. J.Lab. Clin. Med., St. Louis, 66: $161-7,1965$.

40 - MIJRPHY, B.F.P. \& PATTEE, C.J. Determination of thyroxine utilizing the property of protein-binding. J.Clin. Endocrinol. Metab., Philadelphia, 24 $187-96,1964$.

41 - NAGATAKI, S. Effect of excess quantities of iodide. In: GEIGER, S.R., ed. Handbook of physiology. Washington, American Physiological Society, 1974, v.3: D.329-44.

42 - NORDSIEK, F.W. Effects of added casein on goitrogenic action of different dietary levels of soybeans. Proc. Soc. Exp. Biol. and Med., New York, 110:417-20, 1962.

43 - NORMAS analiticas do Instíuto ndolfo Lutz para anălise de alimentos. 2.ed. São Paulo, Institutó Adolfo Lutz, 1976. v. $1, \quad$ p. $24,37,95$.

Q4 - PEARSE, A.G.E. Histochemistry 3.ed. London, Churchill, 1968. $2 v$.

45 - Pinchera, A.; Macgillivray, M.H.; Grawford, J.D.; Freeman, A. G. Thyroid refractoriness in an athyreotic cretin fed soybean formula. N. Engl. J. Med., Boston, 273:83-7, 1965.

46 - QASIN, S.A. \& STELZIG, D.A. Stimulation of basal metabolic rate of rats fed dried-grass silage flavonoids. J. Nutr., Philadelphia, 103:1658-64, 1973. 
47 - RACKIS, J.J. Biological and physiological factors in soybeans. J. Am. 0i1 Chem. SoC., Chicago, 51:161A-74A, 1974.

48 - REILLY, W.A.; SCOTT, K.G.; WHITE, W.E. Increase of uptake of iodine-131 by the thyroid gland after administration of hesperidine methyl chalcone. Proc. Soc. Exp. Biol. Med., New York, 81:682-3, 1952 .

49 - SAGHIR, A.R.; COWAN, J.W.; SALJI, J.P. Goitrogenic activity of onion volatiles. Nature, London, 211:87, 1966.

50 - SCHINGOETHE, D.J.; AUST, S.D.; THOMAS, J.W. Separation of nouse growth inhibitor in soybeans from trypsin inhibitors. J. Nutr., Philadelphia, 100:739-48, 1970.

51 - SCHINGOETHE, D.J.; TIDEMANN, L.J.; UCKERT, J.R. Studies in mice on the isolation and characterization of growth inhibitors from soybeans. J. Nutr., Philadelphia, 104: $104-12,1974$.

52 - SCOTT, K.G. \& STREI, L. Effect of bioflavones upon metabolism of iodine and iodinated compounds in the rat. Proc. Soc. Exp. Biol. Med., New York, 81:493-7, 1952.

53 - SHAPIRO, 0. \& GORDON, A. An inlproved method for separation of radioactive thyroid hormone metabolites by the thin-layer chromatography. Proc. Soc. Exp. Biol. Med., New York, 12?:577-9, 1966 .

54 - SHARPLESS, G.R.; PEARSONS, J.; PRATO, G.S. Production of goiter in rats with raw with treated soy bean flour. J. vutr., Philadelphia, 17:545-55, 1939.

55 - SHEPARD, T.H.; PYNE, G.E.; KIRSCHVINK, J.F.; MCLEAN, M.C. Soybean goiter: report of three cases. N.Engl. J. Med., Boston, 262:1099-103, 1960. 
56 - STUDER, H.; KOHLER, H.; BÜRGI, H. Iodine deficiency. In: GEIGER, S.R., ed. Handbook of physiology. Washington, American Physiological Society, 1974. v.3, p.303-28.

57 - SUWA, J. \& KIMURA, S. Isolation and goitrogenic activity of soybean elements which affect thyroid function. Annu. Rep. Fac. Educ., Gunma Univ., Art. Technol. Healio Phys. Educ., Sci. Hum. Living Ser., Maebashi, 17:71-78, 1981.

58 - SUWA, J.; KOYANAGI, T.; KIMURA, S. Studies on soybean factors which produced goiter in rats, J. Nutr. Sci. Vitaminol., Tokyo, 25:309-15, 1979 .

59 - TAUROLi, A. Hormone synthesis. In: DeGROOT, L.J. ed. et alii Endocrinology. New York, Grune \& Stratton, 1979. V.1, p. $331-42$.

60 - VAN ETTEN, C.H. Goitrogens. In: LIENER, I.E. Toxic constituents of plant foodstuffs. New York, Academic Press, 1969.p. 103-42.

61 - VAN MIDDLESWORTH, L. Thyroxine excretion, a possible cause of goiter. Endocrinology, Springfield, 61:570-3, 1957.

62 - VAN SOEST, P.J. \& WINE, R.H. Use of detergent in the analysis of fibrous feeds. IV. Determination of plant cell-wall constituents. J.Assoc. Off. Anal. Chem., Washington, 50 : $50-5,1967$.

63 - VAN WYK, J.J.; ARNOLD, M.8.; WYNN, J.; PEPPER, F. The effects of a soybean product on thyroid function in humans. Pediatrics, Springfield, 24:752-60, 1959.

64 - WILGUS JR., H.S.; GASSNER, F.Z.; PATTON, A.R.; GUSTAVSON, R.G. The goitrogenicity of soybeans. J.Nutr., Philadelphia, 22: $43-52,1941$. 
65 - WILLS JUNIOR, J. H. Goitrogens in foods. In: TOXICANTS ocurring naturally in foods. Washington, National Academy of Science, 1966. p.3-17.

66 - WOLF, W.J. \& COWAN, D. Soybean as a food source. CRC Crit. Rev. Food Technol., Cleveland, 22:81-158, 1971.

67 - WOLF, W.J. \& THOMAS, B.W. Thin layer and anion exchange chromatography of soybean saponins. J. Am. Oil Chem. Soc., chicago, $47: 86-90,1970$.

68 - WOLFF, J. Transport of iodide and other anions in the thyroid gland. Physiol. Rev, Washington, 44:45-90, 1964.

69 - YAMADA, T.; KAJIHARA, A.; TAKEMURA, Y.; ONAYA, T. Antithyroid compounds. In: GEIGER, S.R., ed. Hancbook of physiology. Washington, American Physiological Society, 1974, v. 3, p. $345-57$. 
RESUMO

Produtos de fracionamento da Farinha de Soja Desengordu rada e Autoclavada foram administrados a ratos para avaliar sua ação na tireóide, em ensaios desde 7 atē 84 dias de duração.

Fraçōes de baixo peso molecular, solüveis em āgua e ace tona, quando avaliadas em ensaios agudos, de 24 hs ou "in vitro", provocaram uma diminuição na captação de $[-131$. Porēm, quando ava liados em raçōes, em experiências de até 84 dias de duração, mesmo em condições de restrição de iodo, não apresentaram efieito sig nificativo.

Por outro lado, identificou-se um fator, associado às fraçōes de alto peso molecular, que induz, jä a partir de 14 dias, quan do administrado em raçōes com restrição em iodo, um aumento no peso da tireōide, redução na captação de $I^{131}$; alteraçōes na sĩntese dos hormōnios e seus precursores a nivel glandular. Em ensaios mais longos (84 dias), provoca uma diminuição de $\mathrm{T}_{4}$ sérico e uma rarefação bastante significativa no colóide do folículo glan dutar.

Por sua vez, a hidrōlise de uma das frações de alto peso molecular, por pepsina e pancreatina, não e capaz de inativar a ação desse fator.

o seu mecanismo de ação parece ser semelhante ao áe substāncias que agem a nīvel de captação de iodo pela tireóide. 


\section{SUMMARY}

Defatted autoclaved soybean flour presented a water/ /acetone soluble fraction which is able to depress I-r37uptake by rat thyroids tested in $24 \mathrm{hs}$ "in vivo" or in 3 hs "in vitro" assays. When this fraction was given to rats in ration with either normal or deficient iodine content for periods from 7 to 84 days no significant action was detected.

On the other hand a factor associated to the high molecular weight protein fraction was identified. The factor is active in rats starting from 14 days after ingestion, in rations with low iodine content producing: increase in thyroid weight, lowering of I-131 uptake, alteration on MIT/DIT, $\mathrm{T}_{3} / \mathrm{T}_{4}$ ratios and after 84 days of administration a significant reduction of serum $\mathrm{T}_{4}$ and a large decrease of the colloid content of foliticle.

Hydrolysis by pepsin or pancreatin does not eiminate the observed action. The mechanism of action of this factor seems to the related to a blockage of the iodine uptake. 